Pegem Journal of Education \& Instruction, 4(2), 2014, 45-74

Pegem Eğitim ve Öğretim Dergisi, 4(2), 2014, 45-74

www.pegegog.net

\title{
The Examination of Relationships Between Emotional Intelligence Levels and Creativity Levels of Pre-serviceTeachers in the Teaching-Learning Process and Environments
}

\author{
Bilal DUMAN ${ }^{*}$, Güler GÖÇEN ${ }^{a}$, Ali YAKAR ${ }^{a}$
}

${ }^{a}$ Muğla Sıtkı Koçman University, Faculty of Education, Muğla /Turkey

\section{Article Info}

DOI: $10.14527 /$ pegegog.2014.009

Article history:

Received 20 May 2013

Revised 11 December 2013

Accepted 02 March 2014

Keywords:

Emotional intelligence,

Creativity,

Learning,

Thinking

Teacher education.

\begin{abstract}
The aim of this study is to examine the relationship between emotional intelligence levels and creativity levels of pre-service teachers in the process of constructing educational system in Turkey. In the study, mixed methods which include qualitative and quantitative data were used. The study was done in 2011-2012 academic year with the participation of the students of Muğla University, Faculty of Education, Departments of Elementary Science Teaching, Elementary School Teaching, Pre-School Teaching, Elementary Social Sciences Teaching, Turkish Language Teaching and English Language Teaching. The questionnaire which was adapted to Turkish language by Tatar et al. (2011) "Emotional Intelligence Questionnaire" was used to determine the preservice teachers' emotional intelligence levels. Additionally, the questionnaire which was adapted to Turkish language by Aksoy (2004) "How Creative Are You?" was used to determine the pre-service teachers' creativity levels. And "Personal Data Form" was used to collect personal data of the pre-service teachers. For the collection of qualitative data, semi-structured interview form prepared by the researchers, and "Personal Data Form" were used to. In order to analyze the quantitative data, "t test" and one-way anova were used. Both critical and interpretive analysis techniques were applied together in the analysis of the qualitative data. According to results of the study, it was determined that emotional intelligence levels of pre-service teachers vary significantly based on gender; yet, no significant difference based on grade level and department was observed. Additionally, it was determined that creativity levels of preservice teachers vary significantly depending on department, but no significant difference is observed based on gender and grade level. And finally, it was determined that there was positive and significant relationship at a low level between emotional intelligence levels and creativity levels of pre-service teachers.
\end{abstract}

\section{Introduction}

The age we live is described as a time period which has undergone a lot of innovations in many areas and in which the traditional approaches have given their places to the new ones. Those developments effecting social, political and economical areas also have brought innovations to the paradigms of education. This fast change in our age, have also highly changed the expectations of the society from education and educated individuals. The aim of the education is to train people who can interrogate, investigate, know how to access information, how to use it properly and have higher order thinking skills rather than to train individuals having all the contextual knowledge.

Thoughts and emotions are concepts that need to be considered together. While Özcan (2000) states that emotions form a basis for thoughts, Goleman (2005) remarks that emotions and thoughts are indispensable for each other. In this regard, while improving the creative thinking skill, which is one of the higher order thinking skills and takes place among the aims of education to train qualified

* Corresponding author: bduman@mu.edu.tr 
individuals, considering the emotional intelligence competences of the individuals is an important factor.

\section{Creativity}

In order to talk about creativity, one of the subjects being discussed by the researchers nowadays, one should maintain this concept closely. There are a lot of definitions of creativity in literature. By defining creativity as "a process of generating ideas for hypothesis, testing hypothesis, and correlating the results", Torrance (1995) emphasized the need for defining creativity as a process rather than defining it as an outcome about personality, product or environment (p.21). Rawlinson (1995) indicated that creativity was a process of generating new ideas, which requires imagination and leads an individual to many plausible answers, solutions and thoughts (p.16). Saaty (2006) also defined creativity as an ability to demonstrate originality and imagination as well as ordinary skills in problem solving.

Although there are a lot of definitions related to creativity, it can be observed that they are fundamentally similar to each other. Especially, in those definitions, it can be maintained that creativity is taken as the forefront of the skills for generating different solutions for problems (Senemoğlu, 2005), making new connections between events, presenting new solutions (Özözer, 2008) and for creating new products (Yenilmez \& Yolcu, 2007). When those definitions about creativity are evaluated, it can be said that creativity is a thinking skill which allows looking at phenomena in different ways, developing original and solution centered ideas for problematic situations, playing with the limits of mind rather than playing within the limits.

In order to understand the importance of creativity for individuals, one should look at the characteristics of people who are evaluated as creative individuals. Creative persons are the ones who put forward ideas and opinions boldly, are inquisitive, are independent in thought and provisions, give themselves fully in the work that they deal with, are regularly busy with the work they deal with, have strong intuition, are persistent, are unwilling to immediately accept everything as the authority says so, take risks (courageous), refuse to accept the provisions of authorities (Arık, 1987, p.11). When those characteristics are taken into account, the importance of creative people can be understood more clearly.

In terms of educational sciences, what comes to mind is questions like "how high order thinking skills such as creativity can be improved for individuals?", "with which factors is it related? "and " how can it be applied in education?" and "In what ways can it be located in curriculum?". It is indicated that creativity is a power which can be learnt and developed (Çellek, 2005). In this respect, Orhon (2011) emphasized that the main role of education is to provide learners with environments for improving their creative thinking skills in every field, and to encourage learners to enhance their abilities (p.22). Training creative individuals and arranging teaching-learning environments for improving their skills are among the tasks of educators. In this context, in order to train creative learners, it is necessary that teachers should be trained as individuals who are always open to trying new experiences and ideas and analyze events from different views (Öztürk \& Darıca, 2003). On this point, Maloney (1992) investigated the effect of teachers' creativity training on their own creativity and their approaches for teaching. According to that study, both the teachers, who took the creativity course and their students try new methods, take risks, give importance to emotions and apply cooperative learning (Cited in Çetingöz, 2002). Therefore, according to results of this study, it can be an important step to determine the creativity levels of the pre-service teachers who will be teachers in the future, and to provide appropriate teaching-learning conditions for improving this ability. 


\section{Emotional Intelligence}

The term emotional intelligence is a concept referring to recognition of both the others and ones' own feelings, self-motivation, and the ability to manage emotions for ourselves and in our relationships (Goleman, 2000). According to Salovey and Mayer (1990), who defined emotional intelligence in their "Emotional Intelligence" works, emotional intelligence can be defined as a type of social intelligence including skills such as monitoring the others and one's own feelings, recognizing the difference between them and applying this information to direct their ideas and actions. In another study, Mayer and Salovey (1993) defined the scope of emotional intelligence by indicating that it includes the verbal and non-verbal evaluation, the expression of feelings, the regulation of others' and their own feeling, the application of emotional content in problem-solving. Cooper and Sawaf (2000), who indicated the effects of emotional intelligence on one's life, mentioned that emotional intelligence not only ensures learning to recognize and evaluate others and our own feelings but also it enables us to react properly by reflecting the information about feelings and the energy of emotions in our daily life and work (p.253). In terms of those definitions, emotional intelligence can be expressed as the one's awareness of his/her feelings as well as others and the ability to recognize and manage emotions and the consciousness of knowing when, where, how to use those emotions.

Dutoğlu and Tuncel (2008), who underlined the necessity of the improvement of emotional intelligence for creating a high quality of life, remarked that individuals who have high emotional intelligence can enhance the belief that "one can do anything" and meanwhile they can reduce the effects of negative feelings like anxiety, worry by using their ability to control their emotions. If the fact that emotional intelligence can be learned (Goleman, 1998) and be improved by education (Kocayörük, 2004) is taken into account, incorporating emotional intelligence into education may help individuals to have characteristics needed for a high quality of life. In order to enhance such a competence for students, teachers should take a major responsibility for it. Teachers should improve the students' abilities such as evaluating different views, making empathy with others, being sensitive to the ideas and feelings of their friends, giving possible solutions to the problems they may face, communicating effectively and working cooperatively with others. If teachers express to students that they understand the students' emotions or make them feel this, students may learn those behaviors implicitly or explicitly and exhibit those behaviors to their friends and teachers (Dutoğlu \& Tuncel, 2008). Coetzee and Jansen (2007) indicate that emotional intelligence enhances the knowledge and skills needed by teachers for creating a classroom environment where students are peaceful. Coetzee and Janson (2007) who indicated that student are motivated in such cases when teachers approach students with respect, sincerity and empathy, emphasize that teachers are models for teaching the management of social and emotional skills through displaying emotional and intelligent behavior. In this direction, it is necessary that the emotional intelligence of teachers and pre-service teachers and the improvement of their emotional intelligence should be determined.

\section{The Relationship between Creativity and Emotional Intelligence}

Thoughts and emotions are interconnected concepts. Emotions take an active role for thinking processes. Emotions often rank first in brain function and helps cognitive learning. If we love the things we learn, we may focus more and move our thoughts into the high order level of thinking processes. When we hate learning, mostly we spend less time for it and we remain in the lowest level of processes (Duman, 2007, p.402). Related with this subject, San (2002), emotions incorporates rationality inside emotions and also emotions and sensitivity contribute to rationality and she defends the idea of this connection between emotions and rationality.

When the relationship between thoughts and emotions is taken into account, gaining the competencies for creativity and emotional intelligence together has a great effect on achieving success. In this direction, there are studies investigating the relationship between emotional intelligence and creativity. Zhou-George (2003) investigated the situation of the leaders' emotional intelligence in the 
creativity processes; Cengiz, Acuner and Baki (2006), investigated the relationship between creativity process and the whole components of emotional intelligence; Akkan (2010), investigated the emotional intelligence of gifted students and its relation with the creativity; Tekin Bender (2006), investigated the level of emotional intelligence of students in Art Education and their level of creativity; also Dadvar, Mohamadrezaii and Fathabadi (2012) analyzed the emotional intelligence of high school students and its relation with creativity. In those studies, it was found that emotional intelligence affects the creative process and it was indicated that they are interconnected with each other.

Consequently, it is observed that all of these studies are conducted with students and leaders except one study conducted with pre-service teachers and the main focus of those researches was to investigate the relationship between emotional intelligence and creativity. Hence, the problem situation of this study is to determine to what extent pre-service teachers have those abilities. It is considered that this study fills the gap in the literature and makes contribution for the future researches.

\section{Method}

\section{Research Design}

In this research, the mixed type of research model, in which both of the qualitative and quantitative data are used, is applied. The reason why the qualitative data are used as well as quantitative data is to investigate the data more deeply and to understand the research subject more broadly (Yıldırım \& Şimşek, 2005). As for the qualitative data, the relational screening model is used. According to Karasar (2005, p.77), the relational screening model is a research approach, which aims to depict a situation existing in past or present in its available form. As for the qualitative data, semi-structured interview is used.

\section{Participants}

The population of study consisted of pre-service teachers who are studying in Faculty of Education in Muğla University in the academic year of 2011-2012. The sample of the study consists of 172 female and 106 male students studying within the grades of 1 and 4 and who are in the departments of Elementary School Teacher Training Education, Preschool Teacher Training Education, Teacher of Social Studies Training Education, Science Teacher Training Education, Turkish and English Language Training Teacher Education in the 2011-2012 academic years.

Table 1.

Distribution of Pre-Service Teachers Participating in Research in terms of Gender, Department and Grade Variables.

\begin{tabular}{llrr}
\hline Variables & Categories & $\mathbf{N}$ & $\mathbf{\%}$ \\
\hline Gender & 1. Female & 172 & 61.4 \\
& 2. Male & 106 & 37.9 \\
\hline Department & 1. Science Teacher Training Education & 15.0 \\
& 2. Elementary School Teacher Training Education & 42 & 16.8 \\
& 3. Preschool Teacher Training Education & 47 & 16.8 \\
& 4. Teacher of Social Studies Training Education & 60 & 21.4 \\
& 5. Turkish Language Training Teacher Education & 48 & 17.1 \\
& 6. English Language Training Teacher Education & 34 & 12.1 \\
\hline Grade & 1. First Grade & 152 & 54.3 \\
& 2. Fourth Grade & 126 & 45.0 \\
& TOTAL & 278 & 100.0 \\
\hline
\end{tabular}




\section{Instrument}

\section{Emotional intelligence scale}

Schutte Emotional Intelligence Scale which was developed by Schutte et.al. (1998) to determine the level of emotional intelligence of pre-service teachers and adapted form of Turkish by Tatar, Tok and Saltukoğlu (2011) is used. The scale, which is a Likert-type scale consisting of 41 items scored on from 1 to 5 was used in this study. Individuals are asked to what extent they agree or disagree with each item. There are five options determining the degree of participation in each item, which are "Strongly Agree", "Agree", "No idea", "Disagree" and "Strongly Disagree". The results of KMO sampling adequacy statistic which is applied in factor analysis, have demonstrated the suitability of correlations between items for factor analysis (KMO $=0.92)$. In addition, according to Bartlett Sphericity Test results, there are sufficient relationship among the items for factor analysis $\left(\chi_{(820)}^{2}=16,705.78, p<0.001\right)$. For the whole scale Cronbach's alpha internal consistency coefficient was 0.82 (Tatar, Tok, \& Saltukoğlu, 2011). For this study, Cronbach's alpha internal consistency coefficient was found to be 0.90 .

\section{Creative thinking skills scale}

"How creative are you?" Scale which was developed by Whetton and Cameron (2002) to determine the level of creativity of pre-service teachers and adapted to Turkish by Aksoy (2004) was used in this study. The scale consisting of 39 items is a 3 point likert type scale. Individuals are asked to what extent they agree and disagree with each item. There are three options determining the degree of participation in each item which are "Agree", "Undecided", "Disagree". Aksoy (2004) found that the Cronbach's alpha reliability coefficient of the scale was 0.94 . In this study, the reliability coefficient was calculated as 0.90 .

\section{Semi-structured interview form}

"Semi-structured interview form" was prepared by the researchers for qualitative data collection. To ensure the validity of the form, expert opinion was taken and some questions were rearranged and some of them were removed according to the recommendations made by the experts. The some part of questions were updated and corrected through pilot applications and they were given the final shape. 4 male and 4 female, totally 8 volunteer teachers were interviewed with the semi-structured interview form consisting of five questions. The information about departments, grades and gender of teachers has been elicited with Personal Information Form.

\section{Data Collection}

The scales used in the study were applied to the participants in groups by the researches. Moreover, by having semi-structured interviews with the participants in 30 minutes time, qualitative data were attained.

\section{Data Analysis}

Data was analyzed with SPSS 17.0 package software. To determine whether pre-service teachers' emotional intelligence and creativity levels according to several variables changed or not, "t test" for the pairwise comparisons, one-way analysis of variance technique for the multivariate comparisons were used. The relationship between emotional intelligence and creativity levels of pre-service teacher was examined by Pearson's Product Moment correlation coefficient. All statistical level of significance was taken as 0.05 in the accounts. 
For the analysis of the qualitative data obtained from semi-structured interviews, critical and interpretive analysis (Creswell, 1998; Hatch, 2002; Merriam, 1998) techniques which are based on critical theory and in which researchers interpret their thoughts and comments on the study are used together. According to Merriam (1998), qualitative data, breaking down the data and analyzing it facilitate the interpretation and data analysis.

\section{Results}

The research findings related to the sub-problems are given in this section of the study.

\section{The Findings for the First Sub-Problem}

In order to answer the first sub-problem which is " Are there any significant differences among levels of the emotional intelligence of pre-service teachers, their departments and their class levels?", the preservice teachers total emotional intelligence scores were calculated. To examine whether pre-service teachers' emotional intelligence scores showed a significant difference in terms of gender or not, t-test was applied, related analysis are given in Table 2.

Table 2.

The t-test Results of Emotional Intelligence Scores in terms of Gender Variable.

\begin{tabular}{lcccccc}
\hline Gender & $\mathbf{N}$ & $\overline{\boldsymbol{X}}$ & $\mathbf{S}$ & $\mathbf{S d}$ & $\boldsymbol{t}$ & $\mathbf{p}$ \\
\hline Female & 172 & 145.30 & 23.49 & 276 & 2.265 & .024 \\
Male & 106 & 138.96 & 20.65 & & & \\
\hline
\end{tabular}

In Table 2, in terms of gender variable, it can be observed that there is a significant difference for the teachers' emotional intelligence scores $(t=2.265 p<.05)$. The mean scores $(\bar{X}=145.30)$ that female preservice teachers got from "emotional intelligence scale" are higher than the male ones $(\bar{X}=138.96)$.

In terms of grade variable, to examine whether there is a significant difference for the pre-service teachers' emotional intelligence scores t-test was applied, the results of analysis are given in Table 3.

Table 3.

The t-test Results of Emotional Intelligence Scores in terms of Grade Variable.

\begin{tabular}{lcccccc}
\hline Class Level & $\mathbf{N}$ & $\overline{\boldsymbol{X}}$ & $\mathbf{S}$ & $\mathbf{S d}$ & $\boldsymbol{t}$ & $\mathbf{p}$ \\
\hline First Grade & 152 & 141.81 & 21.74 & 276 & .859 & .391 \\
Fourth Grade & 126 & 144.18 & 24.16 & & & \\
\hline
\end{tabular}

As seen in Table 3, there is no significant difference between the scores of first grade pre-service teachers for emotional intelligence scale and the scores of fourth grade pre-service teachers for emotional intelligence scale, in terms of grade level variable $(t=.859, p>.05)$.

To examine whether there is a significant difference for prospective teachers' emotional intelligence scores in terms of departments one-way analysis of variance was conducted and related analysis results are given in Table 4. 
Table 4.

The One-Way Variance Analysis Result of Emotional Intelligence Scores in terms of Department Variable.

\begin{tabular}{lrrrrr}
\hline Department & $\begin{array}{r}\text { Sum of } \\
\text { Squares }\end{array}$ & Sd & Mean Square & F & p \\
\hline Between groups & 5505.015 & 5 & 1101.003 & 2.150 & .060 \\
Within-Group & 139280.528 & 272 & 512.061 & & \\
Total & 144785.543 & 277 & & & \\
\hline
\end{tabular}

As seen by Table 4, there is no significant difference among the emotional intelligence scores of preservice teachers who are in the departments of Science Education, Elementary School Education, Turkish and English Education in terms of department variable ( $F=2.150, p>.05)$.

\section{The Findings for the Second Sub-Problem}

In order to answer the second sub-problem, which is "do the results show a significant difference in terms of four variables: the creativity levels of pre-service teachers, their genders, their departments, and their class levels?" the total creativity scores are calculated. So as to examine whether pre-service teachers' creativity scores show a significant difference in terms of gender or not, t-test was applied, and the related analysis are given in Table 5.

Table 5.

The t-test Results of the Creativity Scores in terms of Gender Variable.

\begin{tabular}{lcccccc}
\hline Gender & $\mathbf{N}$ & $\overline{\boldsymbol{X}}$ & $\mathbf{S}$ & Sd & $\boldsymbol{t}$ & $\mathbf{p}$ \\
\hline Female & 172 & 47.05 & 16.88 & 276 & .933 & .352 \\
Male & 106 & 45.14 & 16.22 & & & \\
\hline
\end{tabular}

As seen by Table 5, it can be observed that there is no significant difference for the teachers' creativity scores in terms of gender variable $(t=.933, p>.05)$. With regard to grade variable, to examine whether there is a significant difference for the pre-service teachers' creativity scores or not, t-test was applied, and the results of analysis are given in Table 6.

Table 6.

The t-test Results of the Creativity Scores in terms of Grade Variable.

\begin{tabular}{lcccccc}
\hline Class Level & $\mathbf{N}$ & $\overline{\boldsymbol{X}}$ & $\mathbf{S}$ & $\mathbf{S d}$ & $\boldsymbol{t}$ & $\mathbf{P}$ \\
\hline First Grade & 152 & 46.44 & 16.85 & 276 & .132 & .895 \\
Fourth Grade & 126 & 46.18 & 16.41 & & & \\
\hline
\end{tabular}

As seen by Table 6, it can be remarked that there is no significant difference for the teachers' creativity scores in terms of grade variable $(t=.132, p>.05)$. In order to examine whether there is a significant difference for prospective teachers' creativity scores in terms of their departments or not, one-way analysis of variance was performed and the related analysis results are given in Table 7 and Table 8.

As seen by Table 7, it can be indicated that the highest scores for creativity belong to the pre-service teachers in Pre-school Teacher Training Department. 
Table 7.

The Mean Values of Creativity Scores in terms of Department Variable.

\begin{tabular}{lccc}
\hline Department & $\mathbf{N}$ & $\overline{\boldsymbol{X}}$ & Ss \\
\hline Science Education & 42 & 44.1667 & 14.45754 \\
Elementary School Teacher Training Education & 47 & 41.7872 & 14.55714 \\
Pre-school Teacher Training Education & 47 & $\mathbf{5 1 . 4 4 6 8}$ & 17.73453 \\
Social Sciences Teacher Training Education & 60 & 49.3667 & 16.82710 \\
Turkish Teacher Training Education & 48 & 45.4167 & 18.33823 \\
English Teacher Training Education & 34 & 44.1176 & 15.73409 \\
\hline Total & 278 & 46.3273 & 16.63184 \\
\hline
\end{tabular}

Table 8.

The One-Way Variance Analysis Result of Creativity Scores in terms of Department Variable.

\begin{tabular}{lrrrrrr}
\hline Intergroups & $\begin{array}{r}\text { Sum of } \\
\text { Squares }\end{array}$ & Sd & $\begin{array}{r}\text { Mean } \\
\text { Square }\end{array}$ & $\mathbf{F}$ & $\mathbf{p}$ & $\begin{array}{r}\text { Significant } \\
\text { Difference }\end{array}$ \\
\hline Within-Group & 3156.760 & 5 & 631.532 & 2.337 & .042 & 1,3 \\
Between groups & 73466.452 & 272 & 270.097 & & $2,3-4$ \\
Total & 76623.212 & 277 & & & $3,1-2-6$ \\
& & & & 4,2 \\
& & & & 6,3 \\
\hline 1: Science Education Pre-service Teachers, 2: Elementary School Pre-service Teachers, 3: Pre-School Pre-service Teacher 4: Social
\end{tabular}

As seen in table 8, there is a significant difference in the scores of creativity in terms of department variable $(\mathrm{F}=2.337, \mathrm{p}<.05)$. In other words, the level of creativity of pre-service teachers shows a significant difference in accordance with their departments. According to the LST test results which is applied in order to identify the differences between each department for the groups, there is a significant difference between the departments; between Science Education and Pre-School Education, between Elementary School Education and Social Science Teacher Education, between Pre-School Teacher Education and Science Education; between Elementary School Education and English Teacher Education, between Social Science Teacher Education and Elementary School Teacher Education; and between English Teacher Education and Pre-School Teacher Education.

\section{The Findings for the Third Sub-Problem}

So as to answer the third sub-problem which is "Is there any significant relationship between emotional intelligence levels of pre-service teachers and their creativity levels?", the relationship between emotional intelligence and creativity scores of pre-service teachers is examined by Pearson's Product Moment correlation coefficient.

As can be seen in Table 9, the scores of teachers' emotional intelligence and creativity are correlated at very low levels, but it can be considered that there is a positive and significant relationship between those scores $(r=.119, p<.05)$. 
Table 9.

The Correlation Analysis Results between the Emotional Intelligence and Creativity.

\begin{tabular}{llrr}
\hline & & Creativity & Emotional Intelligence \\
\hline Creativity & Pearson Correlation $(r)$ & 1 & $.119^{*}$ \\
& Significance $(p)$ & & .047 \\
& $N$ & 278 & 278 \\
\hline Emotional & Pearson Correlation $(r)$ & $.119^{*}$ & 1 \\
Intelligence & & & \\
& Significance $(p)$ & .047 & 278 \\
\hline * Correlation is significant at the 0.05 level. & 278 &
\end{tabular}

\section{The Findings for the Fourth Sub-Problem}

The data obtained from the interviews with pre-service teachers were examined; the findings related to the pre-service teachers' responses to questions are given below.

Table 10.

The Answers Pre-service Teachers Gave to the First Question.

\begin{tabular}{|c|c|c|c|}
\hline \multicolumn{4}{|c|}{$\begin{array}{l}\text { Question 1: "Did you find conditions in which you can reflect your emotions on your learning or } \\
\text { you can use your emotional intelligence?" }\end{array}$} \\
\hline $\begin{array}{l}\text { First } \\
\text { Grade } \\
\text { Female }\end{array}$ & $\begin{array}{l}\text { Not too much but in the courses } \\
\text { of some teachers I can find }\end{array}$ & $\begin{array}{l}\text { Fourth } \\
\text { Grade } \\
\text { Female }\end{array}$ & $\begin{array}{l}\text { I have never encountered the } \\
\text { teachers who give importance to } \\
\text { emotions and emotional intelligence. } \\
\text { Maybe in the other universities there } \\
\text { are such teachers. }\end{array}$ \\
\hline $\begin{array}{l}\text { First } \\
\text { Grade } \\
\text { Female }\end{array}$ & $\begin{array}{l}\text { No. Because teachers mostly } \\
\text { prefer presenting their subjects, } \\
\text { they ignore the emotions. }\end{array}$ & $\begin{array}{l}\text { Fourth } \\
\text { Grade- } \\
\text { Female }\end{array}$ & $\begin{array}{l}\text { The important things for the courses } \\
\text { are knowledge and exams. It is not } \\
\text { important what you feel, I think. }\end{array}$ \\
\hline $\begin{array}{l}\text { First } \\
\text { Grade }\end{array}$ & $\begin{array}{l}\text { I still have not understood } \\
\text { whether teacher cared the }\end{array}$ & $\begin{array}{l}\text { Fourth } \\
\text { Grade }\end{array}$ & $\begin{array}{l}\text { In our country the preparation for } \\
\text { exams and exams are the most }\end{array}$ \\
\hline Male & $\begin{array}{l}\text { emotions of other or not. In their } \\
\text { speaking I can sense that they } \\
\text { care but in practice I didn't see } \\
\text { any concrete response. }\end{array}$ & Male & $\begin{array}{l}\text { important things. We enter a lot of } \\
\text { exams and it will also continue after } \\
\text { graduations. If our education system } \\
\text { cares our emotions, we are not } \\
\text { competing with each other like this. }\end{array}$ \\
\hline First & I think there are no conditions & Fourth & We don't have any course where our \\
\hline Grade & like this only the subjects which & Grade & feelings matter. Only in a course I \\
\hline Male & should be brought on time. & Male & $\begin{array}{l}\text { feel myself valuable and it is because } \\
\text { our teacher is someone who gives } \\
\text { value to each one of students. }\end{array}$ \\
\hline
\end{tabular}

When the answers given by first and fourth grade pre-service teachers are examined, it can be observed that they give the similar answers to the questions, but they express that they couldn't find the conditions in which they can use their emotional intelligence. In the light of the answers given by pre-service teachers, the courses that they took in the university aim for cognitive domains whereas the classroom conditions are not prepared appropriately for affective domain and the teaching strategies are not used efficiently to achieve this. 
Table 11.

The Answers Pre-service Teachers Gave to the Second Question.

\begin{tabular}{|c|c|c|c|}
\hline \multicolumn{4}{|c|}{ Question 2: “In the courses you take, are the democratic conditions created?" } \\
\hline $\begin{array}{l}\text { First } \\
\text { Grade } \\
\text { Female }\end{array}$ & $\begin{array}{l}\text { For some courses, yes, for some } \\
\text { courses, no. }\end{array}$ & $\begin{array}{l}\text { Fourth } \\
\text { Grade } \\
\text { Female }\end{array}$ & $\begin{array}{l}\text { No. They have not been provided so } \\
\text { far. }\end{array}$ \\
\hline $\begin{array}{l}\text { First } \\
\text { Grade } \\
\text { Female }\end{array}$ & $\begin{array}{l}\text { Generally they don't provide } \\
\text { them. }\end{array}$ & $\begin{array}{l}\text { Fourth } \\
\text { Grade } \\
\text { Female }\end{array}$ & No they are not provided. \\
\hline $\begin{array}{l}\text { First } \\
\text { Grade } \\
\text { Male }\end{array}$ & $\begin{array}{l}\text { I don't see such a opportunity in } \\
\text { the courses I am taking right now. } \\
\text { Maybe in the future I can see this } \\
\text { in the courses of different } \\
\text { teachers. }\end{array}$ & $\begin{array}{l}\text { Fourth } \\
\text { Grade } \\
\text { Male }\end{array}$ & $\begin{array}{l}\text { No democratic conditions are not } \\
\text { created. Teachers mostly prefer to } \\
\text { teach and work with the successful } \\
\text { students. }\end{array}$ \\
\hline $\begin{array}{l}\text { First } \\
\text { Grade } \\
\text { Male }\end{array}$ & $\begin{array}{l}\text { I didn't see this in the courses I } \\
\text { took in this year }\end{array}$ & $\begin{array}{l}\text { Fourth } \\
\text { Grade } \\
\text { Male }\end{array}$ & $\begin{array}{l}\text { Just in the courses of one teacher } \\
\text { everybody are seen equal but in the } \\
\text { other courses I can't say there is } \\
\text { some kind of equality. }\end{array}$ \\
\hline
\end{tabular}

In the light of the answers given by pre-service teachers, first grade pre-service teachers generally expressed that the democracy and democratic conditions didn't take place in classroom but they remarked that they had expectations and hope for this. Nevertheless, fourth grade pre-service teachers said that the democratic conditions were not provided in the courses. When these data are analyzed, it can be concluded that the general and specific aims of education related to creating democratic conditions in the courses in which students can express their ideas and emotions freely have not been achieved at the desirable levels and the gains of students have not been actualized enough.

Table 12.

The Answers Pre-service Teachers Gave to the Third Question.

\begin{tabular}{|c|c|c|c|}
\hline \multicolumn{4}{|c|}{ Question 3: “Can you make empathy with your friends or teaching stuff?” } \\
\hline $\begin{array}{l}\text { First } \\
\text { Grade }\end{array}$ & $\begin{array}{l}\text { Making empathy with academic } \\
\text { stuff seems to be unlikely but I }\end{array}$ & $\begin{array}{l}\text { Fourth } \\
\text { Grade }\end{array}$ & $\begin{array}{l}\text { I can do it but I don't think that my } \\
\text { teachers make empathy with us. }\end{array}$ \\
\hline Female & $\begin{array}{l}\text { can make empathy with my } \\
\text { friends }\end{array}$ & Female & \\
\hline First & \multirow{2}{*}{$\begin{array}{l}\text { I can make empathy with my } \\
\text { friends. }\end{array}$} & Fourth & I can make empathy with my friends. \\
\hline $\begin{array}{l}\text { Grade } \\
\text { Female }\end{array}$ & & $\begin{array}{l}\text { Grade } \\
\text { Female }\end{array}$ & $\begin{array}{l}\text { Especially because I am in the last } \\
\text { grade level I think everybody has the } \\
\text { same worries.. }\end{array}$ \\
\hline First & \multirow{3}{*}{$\begin{array}{l}\text { I can only make empathy with } \\
\text { some of my friends. }\end{array}$} & Fourth & Even though I can't make empathy \\
\hline Grade & & Grade & with my teachers can make empathy \\
\hline Male & & Male & with my friends. \\
\hline First & \multirow{3}{*}{$\begin{array}{l}\text { I can't make empathy with } \\
\text { others. }\end{array}$} & Fourth & I think that I can make empathy with \\
\hline Grade & & Grade & my teachers. I don't think that they \\
\hline Male & & Male & $\begin{array}{l}\text { can make empathy with me but } \\
\text { sometimes I can make empathy with } \\
\text { my friends. }\end{array}$ \\
\hline
\end{tabular}

If the answers of the pre-service teachers are examined, most of the pre-service teachers in first grade expressed that they couldn't make empathy with teaching stuff, some of them mentioned they could make only empathy with their friends and some of them said they couldn't make empathy with 
others. It seems that the pre-service teachers in the fourth grade have different ideas about empathy from not only their friends at the same level but also from the pre-service teachers at first grade. It can be concluded that the pre-service teachers in the fourth grade can easily make empathy with their friends as well as their teachers; some of them even are examining the concept of empathy by questioning why their teachers don't make empathy with them.

Table 13.

The Answers Pre-service Teachers Gave to the Fourth Question.

\begin{tabular}{|c|c|c|c|}
\hline \multicolumn{4}{|c|}{ Question 4: “Did you find conditions in which you can improve your creative thinking skills?” } \\
\hline $\begin{array}{l}\text { First } \\
\text { Grade }\end{array}$ & At the moment I have not & $\begin{array}{l}\text { Fourth } \\
\text { Grade }\end{array}$ & $\begin{array}{l}\text { No. I could not find throughout 4- } \\
\text { vears in the university }\end{array}$ \\
\hline Female & $\begin{array}{l}\text { believe that there will be courses } \\
\text { developing my creative thinking } \\
\text { skills until graduation. }\end{array}$ & Female & \\
\hline $\begin{array}{l}\text { First } \\
\text { Grade } \\
\text { Female }\end{array}$ & $\begin{array}{l}\text { I could not find in the courses I } \\
\text { took this year. }\end{array}$ & $\begin{array}{l}\text { Fourth } \\
\text { Grade } \\
\text { Female }\end{array}$ & $\begin{array}{l}\text { I cannot find. Each course is identical } \\
\text { to each other. The courses with full of } \\
\text { presentations does not give you the } \\
\text { opportunity to think creatively }\end{array}$ \\
\hline First & For the moment we do not take & Fourth & No. Because rather than thinking, \\
\hline Grade & courses that will develop creative & Grade & knowing is much more important. \\
\hline Male & $\begin{array}{l}\text { thinking. Maybe we can get in a } \\
\text { subsequent period }\end{array}$ & Male & \\
\hline $\begin{array}{l}\text { First } \\
\text { Grade }\end{array}$ & $\begin{array}{l}\text { Such a condition has not been } \\
\text { formed yet. }\end{array}$ & $\begin{array}{l}\text { Fourth } \\
\text { Grade }\end{array}$ & $\begin{array}{l}\text { We don't have courses aiming at } \\
\text { enabling us to think creatively. }\end{array}$ \\
\hline Male & & Male & \\
\hline
\end{tabular}

When the answers of the pre-service teachers are examined, some of the pre-service teachers in first grade remarked that they had expectations for the improvement of their creativity skills but there was no effort made to develop those skills. The pre-service teachers in fourth grade also expressed that they couldn't find learning environment to developing their creativity skills in their educational process. When the answers of the pre-service teachers in first grade are evaluated; it can be stated that they have expectations for the development of their creativity skills because of their first term but so far they haven't seen any effort for improving their creativity. With regard to these data, it can be concluded that the pre-service teachers' education is not enough to satisfy their expectations and needs.

When the answers of the pre-service teachers are examined, it can be observed that the views of the first and fourth grade pre-service teachers are different. Whereas the first grade pre-service teachers believed that they could reach proficiency for their profession in the subsequent courses, the fourth grade pre-service teachers expressed that they couldn't reach proficiency for their profession in terms of creativity activities. In the light of these answers, it can be considered that the pre-service teachers cannot reach the qualifications for using creativity skills and high ordered thinking skills and their education for four years doesn't contribute to those skills in this sense. 
Table 14.

The Answers Pre-service Teachers Gave to the Fifth Question.

\begin{tabular}{|c|c|c|c|}
\hline \multicolumn{4}{|c|}{$\begin{array}{l}\text { Question 5: "In the beginning of your career, do you believe that the creativity activities in your } \\
\text { education are sufficient?" }\end{array}$} \\
\hline $\begin{array}{l}\text { First Grade } \\
\text { Female }\end{array}$ & $\begin{array}{l}\text { We are in the beginning of our } \\
\text { education. But I'm hopeful about } \\
\text { it. University at the end of my life } \\
\text { I think I will gain enough skills } \\
\text { which are necessary for my } \\
\text { profession. }\end{array}$ & $\begin{array}{l}\text { Fourth } \\
\text { Grade } \\
\text { Female }\end{array}$ & $\begin{array}{l}\text { Creativity activities are not enough. } \\
\text { Because of my education was not in } \\
\text { this direction. Every time we take } \\
\text { information based courses. }\end{array}$ \\
\hline $\begin{array}{l}\text { First } \\
\text { Grade- } \\
\text { Female }\end{array}$ & $\begin{array}{l}\text { The education we take will show } \\
\text { us }\end{array}$ & $\begin{array}{l}\text { Fourth } \\
\text { Grade } \\
\text { Female }\end{array}$ & $\begin{array}{l}\text { No. Because they mostly teach us } \\
\text { mundane things. }\end{array}$ \\
\hline $\begin{array}{l}\text { First } \\
\text { Grade- } \\
\text { Male }\end{array}$ & $\begin{array}{l}\text { Right now I don't think that we } \\
\text { take education for creative } \\
\text { activities. I hope this situation will } \\
\text { change in subsequent courses. }\end{array}$ & $\begin{array}{l}\text { Fourth } \\
\text { Grade } \\
\text { Male }\end{array}$ & $\begin{array}{l}\text { Absolutely No. I don't think that the } \\
\text { university education I take is enough } \\
\text { for my professional life. }\end{array}$ \\
\hline $\begin{array}{l}\text { First Grade } \\
\text { Male }\end{array}$ & I don't feel. & $\begin{array}{l}\text { Fourth } \\
\text { Grade } \\
\text { Male }\end{array}$ & $\begin{array}{l}\text { I don't feel. I need to improve myself } \\
\text { when I begin to my Professional life. }\end{array}$ \\
\hline
\end{tabular}

\section{Discussion, Conclusion \& Implementation}

In this study, in which the relationship between creativity and emotional intelligence level of the preservice teachers are examined in the process of teaching and learning, firstly the emotional intelligence and creativity scores are examined in terms of gender, class level and department.

The data collected reveal that the emotional intelligence level of the pre-service teachers has a significant difference in terms of gender and it is in the favor of female pre-service teachers. In other words the emotional intelligence level of female pre-service teacher is higher than the male pre-service teacher. The studies of Bircan (2004), Erdoğdu (2008) and Göcet (2006) indicate a significant difference for the relationship between emotional intelligence and gender in the favor of female subjects. Therefore, the results of our study are relevant with their data. It can be remarked that it is not a surprising result if we take into account the fact that the emotional intelligence of students are shaped in the early childhood and the social role of the Turkish women, because the roles taken by the women require them to have more responsibility. In this sense, it can be considered that the factors such as the facts that women are more aware of their feelings than men, they are making more empathy with others, they have more responsibility than men; provide them with higher emotional intelligence than male ones.

With regard to these analyses, the emotional intelligence level of pre-service teachers shows no significant difference in terms of grade. The results of the study done by Tekin Bender (2006) are in the same direction with our results as the emotional intelligence of pre-service teachers shows no significant difference in every aspect of emotional intelligence. It can be considered that the results showing no significant difference for the emotional intelligence level of pre-service teachers who are in first and fourth grades reveals that the education they take doesn't promote improving their emotional intelligence. The results of the interviews also support the idea that the pre-service teachers' education lacks creating teaching-learning conditions in which they gain some competence and develop these qualifications.

The results obtained from the data analysis, which seeks whether the emotional intelligence level of pre-service teachers changes according to their departments or not, show that there is no significant 
difference for their emotional intelligence and their departments. In a similar study of Önen (2008) there is found no significant difference in terms of the departments of pre-service teachers. What is more even though the emotional intelligence of pre-service teachers in science education has higher average, there is no significant difference in terms of departments in his research.

The results of the data analysis, which investigates whether the creativity level of pre-service teachers has a significant difference in terms of gender or not, reveals that the gender variable doesn't affect their creativity level. The results which are parallel to this study conducted by Yenilmez and Yolcu (2007) show no significant difference for male and female elementary school teachers in terms of gender.

According to the results of analysis, the creativity level of the pre-service teachers doesn't significantly change with respect to grade variable, and there is no significant difference for the elementary school pre-service teachers. Yıldız, Zırhlıoğlu, Yalçınkaya and Güven (2011) indicated that the scores of creativity don't show significant difference in terms of grade. The result of this study also supports this finding. The findings, in which creativity level of pre-service teachers don't change according to class level, present that the training program, in which they are educated, is not appropriate for improving their creativity skills. According to the qualitative data, it can be concluded that first grade pre-service teachers have the expectation of improving their creativity skills through the education they are going to have, whereas the pre-service teachers in fourth grade graduate with the idea that they don't improve their creativity skills and begin their professional life. These situations reveal that pre-service teachers don't meet their expectations about the teaching-learning conditions which should be supportive to improve their creativity skills.

According to the results of the analysis, the creativity level of the pre-service teachers changes significantly with respect to department variable and also there is a significant difference between the departments; between Science Education and Pre-School Education, between Elementary School Education and Social Science Teacher Education, between Pre-School Teacher Education and Science Education; between Elementary School Education and English Teacher Education, between Social Science Teacher Education and Elementary School Teacher Education; and between English Teacher Education and Pre-School Teacher Education. In the study of Temizkalp (2010), which supports this finding, it is remarked that the creativity level of pre-service teachers in terms of department variable.

According to the results about the relationship between the pre-service teachers' emotional intelligence and creativity levels, it can be concluded that there is a positive and significant relationship between them. Cengiz, Acuner and Baki (2006) also remarked that creativity was a process and in this process emotional intelligence made contribution to the development of creativity and so facilitated this process in their study. In a similar study, Dadvar, Mohamadrezaii and Fathabadi (2012) expressed that there was a positive and significant relationship between emotional intelligence and creativity which affects the creativity of students and enables us to predict the level of their creativity. Those results are in the same direction with our findings and support our prediction that there is a relationship between emotional intelligence and creativity. Therefore, in the case of improving high order thinking skills such as creativity, the emotional intelligence of students also should be taken into consideration.

The views of the first and fourth grade pre-service teachers about the opportunities for developing their emotional intelligence and creativity are examined. It can be remarked that they have expectations for the development of their creativity skills but so far they haven't seen any effort and activity for improving their creativity. In comparison to those results, it is determined that the disappointment of the fourth grade pre-service teachers about learning and teaching emotional intelligence and creativity is at the forefront. Whereas first grade pre-service teachers believe that it is possible to develop the skills for creativity and emotional intelligence, fourth grade pre-service teachers express that there is no condition for this. With regard to the results from qualitative interviews, the courses which the preservice teachers take are arranged for the cognitive domain but the conditions for the teaching and learning process of affective domain are not arranged; they can't find any democratic conditions; they 
can't develop their abilities for showing empathy but the students who have individual awareness can make empathy with others not because of the teaching and learning conditions and processes in the courses but because of their abilities; there are not enough efforts to develop creativity skills in the context of both courses and the activities in the courses; the pre-service teachers cannot arrive at the competency level for creative thinking skill, which is one of the high order thinking skills.

In the light of the data obtained from the research, these recommendations can be given in order to improve the level of the emotional intelligence and creativity of pre-service teachers:

1. The results of this study are restricted with the sample in which the data is collected. Hence it is not supposed to make generalization for all the pre-service teachers. So as to increase the likelihood of generalizability for those results, a more comprehensive sample which includes the pre-service teachers from different universities can be applied for similar studies.

2. By increasing the studies in which the relationship between the emotional intelligence and creativity is examined, the gap in the literature should be filled. With regard to the principle that emotions foster thoughts and thoughts foster emotions, the activities based on the both emotions and thoughts should be applied.

3. In the light of our study, the emotional intelligence and creativity of pre-service teachers don't show significant change through their education life. In this respect, the gain, the content, the learning and teaching process and measurement and evaluation dimensions of curriculums in the institutions for training teachers should be constructed in relation with creativity and emotional intelligence, with the sensitivity of the teaching stuff as the operators of curriculum for developing those abilities, the level of emotional intelligence and creativity of pre-service teachers can be increased.

4. As a solution for the physical conditions of the schools where the pre-service teachers can enhance their creativity and emotional intelligence, required actions should be performed. 
Pegem Journal of Education \& Instruction, 4(2), 2014, 45-74

Pegem Eğitim ve Öğretim Dergisi, 4(2), 2014,45-74

www.pegegog.net

\section{Öğretmen Adaylarının Öğrenme-Öğretme Süreç ve Ortamlarında Duygusal Zekâ ve Yaratıcılık Düzeyleri Arasındaki İlişkinin İncelenmesi}

\section{Bilal DUMAN ${ }^{2}$, Güler GÖÇEN ${ }^{a}$, Ali YAKAR ${ }^{a}$}

${ }^{a}$ Muğla Sıtkı Koçman Üniversitesi, Eğitim Fakültesi, Muğla/Türkiye

\section{Makale Bilgisi}

DOI: 10.14527/pegegog.2014.009

\section{Makale geçmişi:}

Geliş 20 Mayıs 2013

Düzeltme 11 Aralık 2013

Kabul $\quad 02$ Mart 2014

Anahtar kelimeler:

Duygusal zekâ,

Yaratıcılık,

Öğrenme,

Düşünme,

Öğretmen yetiştirme.

\begin{abstract}
Öz
Bu çalışmanın amacı, Türkiye'de eğitim sisteminin yeniden yapılandırılması sürecinde öğretmen a daylarının duygusal zekâ ve yaratıcılık düzeyleri arasındaki ilişkinin incelenmesidir. Çalışmada nicel ve nitel verilerin birlikte kullanıldığı karma araştırma deseni kullanılmıştır. Çalışma 2011-2012 eğitim-öğretim yılında gerçekleştirilmiştir. Çalışma grubunu Muğla Üniversitesi Eğitim Fakültesi Fen Bilgisi Öğretmenliği, Sınıf Öğretmenliği, Okul Öncesi Öğretmenliği, Sosyal Bilgiler Öğretmenliği, Türkçe Öğretmenliği Ve İngilizce Öğretmenliği Anabilim Dallarında öğrenim gören 278 öğretmen adayı oluşturmaktadır. Öğretmen adaylarının duygusal zekâ düzeylerini belirlemek amacıyla Duygusal Zekâ Ölçeği'nin Tatar ve diğerleri (2011) ta rafından Türkçe' ye uyarlanmış formu, ya ratıcılık düzeylerini belirlemek a macıyla "How creative are you?" adlı ölçeğin Aksoy (2004) tarafından Türkçe' ye "Yaratıcı Düşünme Becerisi Ölçeği" a dıyla uyarlanan hali kullanılmıştır. Nitel verilerin toplanması için de araştırmacılar tarafından hazırlanan yarı yapılandırılmış görüşme formu ve öğrencilerin kişisel bilgilerine ulaşmak için "Kişisel Bilgi Formu" kullanı Imıştır. Nicel verilerin analizinde ikili karşıl aştırmalarda t testi, ikiden çok değişkenli karşılaştırmalarda tek yönlü varyans analizi kullanılmıştır. Nitel verilerin analizinde eleştirel ve yorumlayıcı analiz teknikleri birlikte kullanılmıştır. Araştırma sonucunda öğretmen adaylarının duygusal zekâ düzeylerinin cinsiyet değişkenine göre değiştiği, ancak sınıf seviyesi ve bölüm değişkenlerine göre değişmediği; yaratıcılık düzeylerinin cinsiyet ve sınıf seviyesi değişkenlerine göre değişmediği, bölüm değişkenine göre değiştiği; duygusal zekâ ve ya ratıcılık düzeyleri arasında düşük düzeyde, pozitif ve anlamlı bir ilişki olduğu görülmüştür.
\end{abstract}

Giriş

İçinde bulunduğumuz çağ birçok alanda yeniliklerin yaşandığı, geleneksel yaklaşımların yerini yeni yaklaşımlara bıraktığı bir zaman dilimi olarak tasvir edilmektedir. Toplumsal, siyasal ve ekonomik alanlarda etkisini gösteren bu gelişmeler, eğitim paradigmalarında da yenilikleri gündeme getirmiştir. Çağımızdaki bu hızlı değişim, toplumun eğitimden ve eğitimli insandan beklentilerini büyük ölçüde değiştirmiştir. Eğitimin amacı bütün bilgilere sahip bireyler yetiştirmekten ziyade sorgulayan, araştıran, bilgiye ulaşmanın yollarını bilen, bilgiyi gerektiği yerde gerektiği şekilde kullanabilen, üst düzey düşünme becerilerine sahip bireyler yetiştirmek olmuştur.

Duygu ve düşünce birlikte düşünülmesi gereken kavramlardır.Özcan (2000) duyguların düşüncelerin zeminini oluşturduğunu ifade ederken, Goleman (2005) duygular ve düşüncelerin birbiri için vazgeçilmez olduğunu belirtmiştir. Her anlamda donanımlı bireyler yetiştirmek adına, bireydeki duygu ve düşünceler birlikte düşünüldüğünde; bireylere düşünme becerilerini kazandırma hususunda, onların duygu yapısının da göz ardı edilmemesi gerekmektedir. Bu bağlamda eğitim yoluyla nitelikli bireyler yetiştirmek için belirlenen hedefler arasında yer alan ve üst düzey düşünme becerilerden biri olan yaratıcı düşünme

*Yazar: bduman@mu.edu.tr 
becerisini geliştirirken, bireylerin duygusal zekâ yetkinliklerini de göz önünde bulundurmak önemli bir etmen olarak karşımıza çıkmaktadır.

\section{Yaratıcılık}

Günümüzde tartışılan önemli konulardan biri olan yaratıcılık hakkında konuşmak için bu kavrama daha yakından bakmak gerekmektedir. Bu kavramla ilgili literatürde birçok tanıma rastlanmaktadır. Torrance (1995) yaratıcılığın "hipotezler için fikirler oluşturma, hipotezleri test etme ve sonuçları ilişkilendirme süreci" olduğunu belirterek, yaratıcılığı kişilik, ürün ya da çevre bakımından tanımlamak yerine süreç olarak tanımlamayı seçtiğini vurgulamıştır (s.21). Rawlinson (1995), yaratıcı düşüncenin hayal gücü gerektiren ve insanı pek çok muhtemel yanıta, çözüme ve düşünceye götüren bir fikir üretme süreci olduğunu belirtmiştir (s.16). Saaty (2006) is e ya ratıcılığı problem çözmede alışılagel miş becerilerin yanı sıra orijinallik ve hayal gücü sergileme becerisi olarak tanımlamıştır.

Yaratıcılıkla ilgili çeşitli tanımlar yapılmış olsa da bu tanımların temelde birbirine benzediği görülmektedir. Özellikle bu tanımlarda, yaratıcılığın problemlere farklı çözümler üretme yeteneği olduğu (Senemoğlu, 2005), olaylar arasında yeni bağlantılar kurma, yeni çözümler ortaya koyma (Özözer, 2008) ve yeni ürünler ortaya çıkarma (Yenilmez ve Yolcu, 2007) gibi becerilerin ön planda tutulduğu görülmüştür. Yaratıcılık ile ilgili yapılan bu tanımlar değerlendirildiğinde, yaratıcılığın olaylara farklı açıdan bakma, problematik durumlar karşısında orijinal ve çözüm odaklı fikirler geliştirme ve zihnin sınırlar arasında değil sınırlarla oynamasına imkân sağlayan bir düşünme becerisi olduğu söylenebilir.

Yaratıcı düşünme becerisinin bireyler açısından önemini anlamak için, yaratıcı olarak değerlendirilen insanların özelliklerine bakmak gerekmektedir. Yaratıcı bireyler, fikir ve kanaatlerini cesaretle ortaya atan, mütecessis, düşünce ve hükümlerinde bağımsız, uğraştığı işe tam manasıyla kendini veren, eline aldığı işle devamlı bir şekilde meşgul olan, sezgileri kuvvetli, ısrarlı, otoriteler öyle söylüyor diye her şeyi hemen kabul etmek istemeyen, tehlikeleri göze alan (cüretkâr), otoritelerin hükümlerini kabul etmek istemeyen" bireylerdir (Arık, 1987, s.11). Bu özellikler dikkate alındığında yaratıcılığın bireyler ve toplum açısından önemi daha da iyi anlaşılmaktadır. Yaratıcı bireyler, meraklı, açık fikirli ve yaptıkları işte kararlı olma gibi özellikleri sayesinde bireysel açıdan başarıyı yakalarken, toplumsal açıdan yeniliklere ve ilerlemelere katkı sağlayabilirler.

Eğitim bilimleri açısından ise, bireylerde yaratıcılık gibi üst düzey düşünme becerilerinin nasıl geliştirilebileceği, hangi etmenlerle bağlantılı olduğu, eğitim-öğretimde uygulanabilirliği ve öğretim programlarında ne şekilde yer alacağı gibi konular akla gelmektedir. Yaratıcılığın öğrenilebilen ve geliştirilebilen bir güç olduğu belirtilmektedir (Çellek, 2005). Bu hususta Orhon (2011), eğitimin ana rolünün insan zekâsının her alanındaki yaratıcı düşünme yeteneğini geliştirecek ortamlar üretmek, yeteneklerin işe yarar hale dönüştürülmesini cesaretlendirmek olması gerektiğini belirtmiştir (s.22). Yaratıcı bireyler yetiştirmek ve onların bu becerilerini geliştirecek öğrenme-öğretme ortamlarını düzenlemek eğitimcilerin görevleri arasında bulunmaktadır. Bu bağlamda yaratıcı bireyler yetiştirmek için öğretmenlerin de her zaman için yeni fikirlere ve yenilikleri denemeye açık, farklı bakış açılarından olayları incel eyebilen bireyler olarak yetiştirilmeleri gerekmektedir (Öztürk ve Darıca, 2003). Bu konuda Maloney (1992) yaptığı çalışmada öğretmenlerin yaratıcılık eğitimi almalarının kendi yaratıcılıkları ve öğretim ileilgili yaklaşımları üzerindeki etkisini araştırmıştır. Araştırmada yaratıcılık eğitimi kursu almış olan öğretmenlerin kendilerinin ve öğrencilerinin yaratıcılıklarını geliştirmek için yeni yöntemler denedikleri, risk aldıkları, hislere önem verdikleri ve işbirlikli öğrenmeyi uyguladıkları görülmüştür (Akt. Çetingöz, 2002). Bu nedenle geleceğin öğretmenleri olan öğretmen adaylarının yaratıcılık düzeylerinin belirlenmesi, el de edilen sonuçlar doğrultusunda bu becerinin geliştirilmesini sağlayacak eğitim-öğretim ortamlarının düzenlenmesi yaratıcı bireyler yetiştirmek adına atılması gereken önemli bir adım olarak karşımıza çıkmaktadır. 


\section{Duygusal Zekâ}

Duygusal zekâ kendimizin ve başkalarının hislerini tanıma, kendimizi motive etme, içimizdeki ve ilişkilerimizdeki duyguları iyi yönetme yetisine gönderme yapan bir kavramdır (Goleman, 2000). Duygusal zekâ kavramını "Emotional Intelligence" çalışmalarında tanımlayan Salovey ve Mayer (1990) duygusal zekâyı, kişinin kendisinin ve başkalarının duygularını izleme, aralarındaki farkı görme ve bu bilgiyi düşüncelerinde ve hareketl erinde yönlendirici ola rak kullanma yeteneğini kapsayan sosyal zekânın bir türü olarak ifade etmişlerdir. Bir başka çalışmalarında Mayer ve Salovey (1993) duygusal zekânın sözlü-sözsüz değerlendirme, duyguların ifade edilmesi, kendinin ve başkalarının duygularını düzenleme ve problem çözmede duygusal içeriğin kullanımını içerdiğini belirterek duygusal zekânın kapsamını açıklamışlardır. Duygusal zekânın bireyin yaşantısına olan etkisine vurgu yapan Cooper ve Sawaf (2000), duygusal zekânın kendimizin ve başkalarının duygularını tanımayı ve değerlendirmeyi öğrenmemizin yanı sıra duygulara ilişkin bilgileri ve duyguların enerjisini günlük yaşa mımıza ve işimize etkin bir biçimde yansıtarak onlara uygun tepkiler vermemizi sağladığını belirtmişlerdir (s.253). Yapılan bu tanımlar doğrultusunda duygusal zekâ; kendi duygularının ve başkalarının duygularının farkında olma, duyguları tanıma ve yönetme becerisine sahip olma, duyguları ne zaman, nerede, nasıl kullanacağının bilincinde olma şeklinde ifade edilebilir.

Bireylerde yüksek kalitede bir yaşam oluşturmak adına duygusal zekânın geliştirilmesi gerektiğine vurgu yapan Dutoğlu ve Tuncel (2008), duygusal zekâsı gelişmiş bir kişinin "bir şeyi yapabilme inancı" geliştirebildiğini ve aynı zamanda da duygularını kontrol etme yetisini kullanarak kaygı, endişe gibi olumsuz duygularını en aza indirgediğini belirtmişlerdir. Duygusal zekânın öğrenilebil eceği (Goleman, 2000) ve eğitimle geliştirilebileceği (Kocayörük, 2004) dikkate alındığında, eğitimde duygusal zekâya yer verilmesinin bireylerin daha kaliteli biryaşam oluşturmaya yardımcı olan bu özelliklere sahip olabileceği düşünülebilir. Öğrencilerde bu yetiyi geliştirmek adına öğretmenlere büyük görevler düşmektedir. Öğretmen, öğrencilerde farklı bakış açılarını değerlendirme, arkadaş ilişkilerinde empati kurma, arkadaşlarının düşüncelerine ve duygularına duyarlı olma, karşılaştığı problemlere çözüm önerileri oluşturma, etkili iletişim ve işbirliği içinde çalışma gibi yetileri geliştirmelidir. Öğretmen öğrencilerin duygularını anladığını açıkça dile getirir ya da bunu onlara hissettirirse, öğrenciler de bu davranışları örtülü veya açık bir şekilde öğrenip, arkadaşlarına veya öğretmenine karşı sergileyebilir (Dutoğlu ve Tuncel, 2008). Coetzee ve Jansen (2007), duygusal zekânın öğrencilerin huzurlu olduğu bir sınıf ortamı oluşturmak adına öğretmenlerin ihtiyaç duyduğu bilgi ve becerileri geliştirdiğini belirtmişlerdir. Öğretmenlerin saygı, içtenlik ve empati ile öğrencilere yaklaşması durumunda öğrencilerin motive olduğunu belirten Coetzee ve Janson (2007), öğretmenlerin duygusal akıllı davranış göstererek, öğrencilere sosyal ve duygusal becerilerin yönetimini öğretmek için model olduklarını vurgulamışlardır. Bu doğrultuda öğretmenlerin ve öğretmen adaylarının duygusal zekâ seviyelerinin belirlenmesi ve bu seviyenin yükseltilmesi gerekliliği ortaya çıkmaktadır.

\section{Yaratıcılık ve Duygusal Zekâ Arasındaki ilişski}

Duygu ve düşünce birbirinden ayrı düşünülmemesi gereken kavramlardır. Duygular düşünme sürecinde önemli rol oynar. Duygular beyin işlevinde çoğunlukla ön sırayı alır ve bilişsel öğrenmeye yardımcı olur. Eğer öğrendiğimiz şeyi seversek, daha çok odaklanabilir ve yüksek seviyede düşünmeye doğru hareket edebiliriz. Öğrenmeden nefret ettiğimiz zaman çoğunlukla öğrenmek için çok az zaman harcarız ve en düşük süreç seviyesinde kalırız (Duman, 2007, s.402). Bu konuyla ilgili olarak San (2002), akıl yürütmelerle duygunun içinde ussallığın, ussallıkta da duyguların ve duygululuğun payının bulunduğunu belirtmektedir.

Duygu ve düşünce arasındakibu ilişki göz önüne alındığında kişinin başarıya ulaşmasında yaratıcılık ve duygusal zekâ yetkinliklerini birlikte kazanmasıönemli etkiye sahiptir. Bu doğrultuda duygusal zekâ ve ya ratıcılık a rasındaki i lişkiyi inceleyen çalışmalar bulunmaktadır. Zhou-George (2003), liderlerin duygusal zekâlarının yaratıcılık sürecindeki durumunu; Cengiz, Acuner ve Baki (2006), duygusal zekânın tüm bileşenlerinin yaratıcılık süreci ile ilişkisini; Akkan (2010), üstün yetenekli öğrencilerin duygusal zekâ ve 
yaratıcılık ilişkisini; Tekin Bender (2006), resim-iş eğitimi öğrencilerinin duygusal zekâ ve yaratıcılık düzeylerini; Dadvar, Mohamadrezaii ve Fathabadi (2012) ise lise öğrencilerinde duygusal zekâ ve yaratıcılık ilişkisini incelemişlerdir. Bu çalışmalarda, duygusal zekânın yaratıcılık sürecini etkilediği ve birebir ilişki hâlinde olduğu vurgulanmıştır.

Sonuç olarak duygusal zekâ ve yaratıcılık arasındaki ilişkinin incelendiği bu çalışmaların liderler ve öğrenciler ile yapıldığı, sadece bir çalışmada öğretmen adaylarıyla araştırma yapıldığı görülmüştür. Bu nedenle öğretmen adaylarının bu becerilere ne derece sahip olduğunu belirlemek araştırmanın problem durumunu oluşturmaktadır. Bu çalışmanın ilgilialandaki boşluğu gidereceği ve gelecek çalışmalara katkı sağlayacağı düşünülmektedir. Araştırma problemi çerçevesinde çalışmanın amacı, öğrenme-öğretme süreç ve ortamlarında öğretmen adaylarının duygusal zekâ ve yaratıcılık düzeyleri arasındaki ilişkinin incelenmesidir. Bu amaçla aşağıdaki sorulara cevap aranmıştır:

1. Öğretmen adaylarının duygusal zekâ düzeyleri, cinsiyet, sınıf seviyesi ve bölüm değişkenlerine göre anlamlı bir farklılık göstermekte midir?

2. Öğretmen adaylarının yaratıcılık düzeyleri, cinsiyet, sınıf seviyesi ve bölüm değişkenlerine göre anlamlı bir farklılık göstermekte midir?

3. Öğretmen adaylarının duygusal zekâ düzeyleri ile yaratıcılık düzeyleri a rasında anlamlı bir ilişki var midır?

4. Öğretmen adaylarının öğretim süreci içinde duygusal zekâ ve yaratıcılık düzeylerini geliştirmeye yönelik fırsatlar bulunmasına ilişkin görüşleri nelerdir?

\section{Yöntem}

\section{Araştırma Modeli}

Bu araştırmada, nitel ve nicel verilerin birlikte el de edildiği karma araştırma modeli kullanılmıştır. Nicel yöntemlerin yanı sıra nitel yöntemlerin tercih edilmesinin nedeni, konuya ilişkin daha derinlemesine verilerin elde edilmesine ve konunun daha kapsamlı olarak anlaşılmasına katkı sağlamaktır (Yıldırım ve Şimşek, 2005). Çalışmanın nicel boyutunda ilişkisel tarama modeli kullanılmıştır. Tarama modelleri, Karasar’a (2005) göre, geçmişte veya halen var olan bir durumu, var olduğu şekliyle betimlemeyi amaçlayan araştırma yaklaşımlarıdır (s.77). Çalışmanın nitel boyutunda ise yarı yapılandırılmış görüşme kullanılmıştır.

\section{Katılımcılar}

Araştırmanın evrenini Muğla Üniversitesi Eğitim Fakültesi’nde 2011-2012 eğitim öğretim yılında öğrenim görmekte olan öğretmen adayları oluşturmaktadır. Araştırmanın örneklemini ise 2011-2012 eğitim öğretim yılında Muğla Üniversitesi Eğitim Fakültesi’nde Fen Bilgisi Öğretmenliği, Sınıf Öğretmenliği, Okul Öncesi Öğretmenliği, Sosyal Bilgiler Öğretmenliği, Türkçe Öğretmenliği ve İngilizce Öğretmenliği Anabilim Dallarında birinci ve dördüncü sınıflarda öğrenim gören 172 kız, 106 erkek olmak üzere toplam 278 öğrenci oluşturmaktadır.

\section{Veri Toplama Aracı}

\section{Duygusal zekâ ölçeği}

Öğretmen adaylarının duygusal zekâ düzeyini belirlemek amacıyla Schutte ve diğerleri (1998) tarafından geliştirilen, Schutte Duygusal Zekâ Ölçeği'nin, Tatar, Tok ve Saltukoğlu (2011) tarafından Türkçe' ye uyarlanmış hâli kullanılmıştır. Ölçek 41 maddeden oluşan ve 1-5 arası puanlanan likert tipi bir ölçektir. Her madde için bireylere, ölçekteki maddelere ne derecede katıldıkları sorulmaktadır. Bu maddelere katılma derecelerini belirleyen seçenekler "Kesinlikle Katılıyorum", "Katılıyorum", "Fikrim Yok", "Katılmıyorum" ve "Kesinlikle Katılmıyorum" şeklindedir. Faktör analizinde uygulanan KMO 
Örnekleme Yeterliliği İstatistiği sonuçları, maddel er arası korelasyonların faktör analizine uygunluğunu göstermiştir (KMO=0,92). Ayrıca Bartlett Küresellik Testi sonucuna göre de maddeler arasında faktör analizi yapmak için yeterli düzeyde ilişki vardır $\left(\chi_{(820)}^{2}=16705,78 ; p<0,001\right)$. Ölçeğin bütünü için Cronbach-Alpha iç tutarlık katsayısı 0.82'dir (Tatar, Tok ve Saltukoğlu, 2011). Bu çalışma için CronbachAlpha iç tutarlılık katsayısı 0.90 olarak bulunmuştur.

Tablo 1.

Araştırmaya Katılan Öğretmen Adaylarının Cinsiyet, Bölüm ve Sınıf Seviyesi Değişkenlerine Göre Dağılımı.

\begin{tabular}{llrr}
\hline Değişkenler & Kategoriler & $\mathbf{N}$ & \% \\
\hline Cinsiyet & 1. Kadın & 172 & 61.4 \\
& 2. Erkek & 106 & 37.9 \\
\hline Bölüm & 1. Fen Bilgisi Öğretmenliği & 42 & 15.0 \\
& 2. Sınıf Öğretmenliği & 47 & 16.8 \\
& 3. Okul Öncesi Öğretmenliği & 47 & 16.8 \\
& 4. Sosyal Bilgiler Öğretmenliği & 60 & 21.4 \\
& 5. Türkçe Öğretmenliği & 48 & 17.1 \\
& 6. Ingilizce Öğretmenliği & 34 & 12.1 \\
\hline Sınıf Seviyesi & 1. Birinci Sınıf & 152 & 54.3 \\
& 2. Dördüncü Sınıf & 126 & 45.0 \\
\hline
\end{tabular}

\section{Yaratıcı düşünme becerisi ölçeği}

Öğretmen adaylarının yaratıcılık düzeylerini belirlemek amacıyla Whetton ve Cameron'dan (2002) alınan "How creative are you?" adlı ölçeğin Aksoy (2004) tarafından Türkçe' ye "Yaratıcı Düşünme Becerisi Ölçeği" a dıyla uyarlanan hâli kullanılmıştır. 39 maddeden oluşan ölçek 3'lü likert tipindedir. Her madde için bireylere ölçekteki maddelere ne derecede katıldıkları sorulmaktadır. Bu maddelere katılma derecelerini belirleyen seçenekler "Katılıyorum", "Kararsızım”, "Katılmıyorum” şeklindedir. Aksoy (2004) tarafından ölçeğin güvenirlik katsayısı 0.94 bulunmuştur. Bu çalışmada is e güvenilirlik katsayısı 0.90 olarak hesaplanmıştır.

\section{Yarı-yapılandırılmış görüşme formu}

Nitel verilerin toplanması amacıyla araştırmacılar tarafından yarı yapılandırılmış görüşme formu hazırlanmıştır. Formun geçerliliğini sağlamak amacıyla uzman görüşü alınmış ve uzmanlar tarafından yapılan öneriler doğrultusunda bazı sorular yeniden düzenlenmiş, bazı sorular ise çıkartılmıştır. Pilot uygulamalar yapılarak soruların bir kısmında düzeltmeler yapılmış ve forma son şekli verilmiştir. Beş sorudan oluşan yarı yapılandırılmış görüşme formu ile 4'ü kadın 4'ü erkek olmak üzere 8 gönüllü öğretmen adayıyla görüşme yapılmıştır. Kişisel Bilgi Formu ile de öğretmen adaylarının okudukları bölüm, sınıf ve cinsiyet bilgilerine ulaşılmıştır.

\section{Verilerin Toplanması}

Araştırmada kullanılan ölçekler katılımcılara, araştırmacılar tarafından gruplar halinde uygulanmıştır. Ayrıca katılımcılar ile 30’ar dakikalık yarı yapılandırılmış görüşmeler gerçekleştirilerek nitel veriler elde edilmiştir. 


\section{Verilerin Analizi}

Veriler bilgisayar ortamında SPSS 17.0 paket programı ile analiz edilmiştir. Öğretmen adaylarının duygusal zekâ ve yaratıcılık düzeylerinin çeşitli değişkenlere göre değişiklik gösterip göstermediğini belirlemek amacıyla ikili karşılaştırmalarda "t testi", ikiden çok değişkenli karşılaştırmalarda tek yönlü varyans analizi tekniği kullanılmıştır. Öğretmen adaylarının duygusal zekâ ve yaratıcılık düzeyleri arasındaki ilişkiye ise Pearson Momentler İlişki Katsayısı ile bakılmıştır. Tüm istatistiksel hesaplarda anlamlılık düzeyi 0.05 olarak alınmıştır.

Yarı yapılandırılmış görüşmelerden elde edilen nitel verilerin çözümlenmesi için eleştirel kurama dayalı olan ve araştırmacının çalışma üzerindeki düşüncelerini ve yorumlarını disiplin ettiği ve yorumladığı eleştirel ve yorumlayıcı analiz (Creswell, 1998; Hatch, 2002; Merriam, 1998) teknikleri birlikte kullanılmıştır. Merriam (1998)'a göre nitel verilerin, parçalanarak ve çözümlenerek analiz yapılması verilerin anlamlandırılmasını kolaylaştırmaktadır.

\section{Bulgular}

Bu bölümde araştırmanın alt problemlerine ilişkin bulgulara yer verilmiştir.

\section{Birinci Alt Probleme ilişskin Bulgular}

Çalışmanın birinci alt problemi olan "Öğretmen adaylarının duygusal zekâ düzeyleri, cinsiyet, sınıf seviyesi ve bölüm değiş̧enlerine göre anlamlı bir farklılık göstermekte mi dir?” sorusunu cevaplandırmak için, öğretmen adaylarının toplam duygusal zekâ puanları hesaplanmıştır. Öğretmen adaylarının duygusal zekâ puanlarının cinsiyet değişkenine göre anlamlı bir fark gösterip göstermediğini incelemek için t-testi yapılmış ve ilgili analiz sonuçları Tablo 2'de verilmiştir.

Tablo 2.

Duygusal Zekâ Puanlarının Cinsiyet Değişkenine Göre t-testi Sonuçları.

\begin{tabular}{lcccccc}
\hline Cinsiyet & $\mathbf{N}$ & $\overline{\mathbf{X}}$ & $\mathbf{S}$ & Sd & $\boldsymbol{t}$ & $\mathbf{p}$ \\
\hline Kadın & 172 & 145.30 & 23.49 & 276 & 2.265 & .024 \\
Erkek & 106 & 138.96 & 20.65 & & & \\
\hline
\end{tabular}

Tablo 2 incelendiğinde, cinsiyet değişkenine göre öğretmen adaylarının duygusal zekâ puanlarının anla mlı bir şekil de farklılaştığı görülmektedir $(\mathrm{t}=2.265, \mathrm{p}<.05)$. Kadın öğretmen adaylarının duygusal zekâ ölçeğinden aldıkları ortalama puanlar ( $\bar{X}=145.30)$, erkek öğretmen adaylarının duygusal zekâ ölçeğinden aldıkları ortalama puanlara ( $\overline{\mathrm{X}}=138.96)$ göre daha yüks ektir.

Öğretmen adaylarının duygusal zekâ puanlarının sınıf seviyesi değişkenine göre anlamlı bir fark gösterip göstermediğini incelemek için t-testi yapılmış ve ilgili analiz sonuçları Tablo 3'de verilmiştir.

\section{Tablo 3.}

Duygusal Zekâ Puanlarının Sınıf Seviyesi Değişkenine Göre t-testi Sonuçları.

\begin{tabular}{lcccccc}
\hline Sınıf Seviyesi & $\mathbf{N}$ & $\overline{\mathbf{X}}$ & $\mathbf{S}$ & $\mathbf{S d}$ & $\boldsymbol{t}$ & $\mathbf{p}$ \\
\hline Birinci Sınıf & 152 & 141.81 & 21.74 & 276 & .859 & .391 \\
Dördüncü Sınıf & 126 & 144.18 & 24.16 & & & \\
\hline
\end{tabular}

Tablo 3 incelendiğinde, sınıf seviyesi değişkenine göre öğretmen adaylarının duygusal zekâ ölçeğinden aldıkları puanlar a rasında birinci ve dördüncü sınıf seviyesi ola rak anlamlı bir farklılık ol madığı görülmektedir ( $t=.859, \mathrm{p}>.05)$. 
Öğretmen adaylarının duygusal zekâ puanlarının bölüm değişkenine göre anlamlı bir fark gösterip göstermediğini incelemek için tek yönlü varyans analizi yapılmış ve ilgili analiz sonuçları Tablo 4'de verilmiştir.

Tablo 4.

Duygusal Zekâ Puanlarının Bölüm Değişkenine Göre Tek Yönlü Varyans Analizi Sonuçları.

\begin{tabular}{lrrrrr}
\hline Bölüm & $\begin{array}{r}\text { Kareler } \\
\text { Toplamı }\end{array}$ & Sd & $\begin{array}{r}\text { Kareler } \\
\text { Ortalaması }\end{array}$ & $\mathbf{F}$ & p \\
\hline Gruplararası & 5505.015 & 5 & 1101.003 & 2.150 & .060 \\
Grupiçi & 139280.528 & 272 & 512.061 & & \\
Toplam & 144785.543 & 277 & & & \\
\hline
\end{tabular}

Tablo 4 incelendiğinde, bölüm değişkenine göre Fen Bilgisi Öğretmenliği, Sınıf Öğretmenliği, Okul Öncesi Öğretmenliği, Sosyal Bilgiler Öğretmenliği, Türkçe Öğretmenliği ve İngilizce Öğretmenliği bölümlerinde öğrenim gören öğretmen adaylarının duygusal zekâ puanları arasında anlamlı bir farklılık olmadığı görülmektedir ( $F=2.150, p>.05)$.

\section{İkinci Alt Probleme ilişkin Bulgular}

Çalışmanın ikinci alt problemi olan "Öğretmen adaylarının yaratıcılık düzeyleri, cinsiyet, sınıf seviyesi ve bölüm değişkenlerine göre anlamlı bir farklılık göstermekte midir?” sorusunu cevaplandırmak için, öğretmen adaylarının toplam yaratıcılık puanları hesaplanmıştır. Öğretmen adaylarının yaratıcılık puanlarının cinsiyet değişkenine göre anlamlı bir fark gösterip göstermediğini incelemek için t-testi yapılmış ve ilgili analiz sonuçları Tablo 5'de verilmiştir.

\section{Tablo 5.}

Yaratıcılık Puanlarının Cinsiyet Değişkenine Göre t-testi Sonuçları.

\begin{tabular}{lcccccc}
\hline Cinsiyet & $\mathbf{N}$ & $\overline{\mathbf{X}}$ & $\mathbf{S}$ & Sd & $\boldsymbol{t}$ & $\mathbf{p}$ \\
\hline Kadın & 172 & 47.05 & 16.88 & 276 & .933 & .352 \\
Erkek & 106 & 45.14 & 16.22 & & & \\
\hline
\end{tabular}

Tablo 5 incelendiğinde öğretmen adaylarının yaratıcılık puanlarının cinsiyet değişkenine göre anlamlı bir farklılık göstermediği görülmektedir ( $t=.933, p>.05)$.

Öğretmen adaylarının yaratıcılık puanlarının sınıf seviyesi değişkenine göre anlamlı bir fark gösterip göstermediğini incelemek için t-testi yapılmış ve ilgili analiz sonuçları Tablo 6'da verilmiştir.

Tablo 6.

Yaratıcılık Puanlarının Sınıf Seviyesi Değişkenine Göre t-testi Sonuçları.

\begin{tabular}{lcccccc}
\hline Sınıf Seviyesi & $\mathbf{N}$ & $\overline{\mathbf{X}}$ & $\mathbf{S}$ & Sd & $\boldsymbol{t}$ & $\mathbf{p}$ \\
\hline Birinci Sınıf & 152 & 46.44 & 16.85 & 276 & .132 & .895 \\
Dördüncü Sınıf & 126 & 46.18 & 16.41 & & & \\
\hline
\end{tabular}

Tablo 6 incelendiğinde, öğretmen adaylarının yaratıcılık puanlarının sınıf seviyesi değişkenine göre anlamlı bir farklılık göstermediği görülmektedir ( $t=.132, p>.05)$.

Öğretmen adaylarının yaratıcılık puanlarının bölüm değişkenine göre anlamlı bir fark gösterip göstermediğini incelemek için tek yönlü varyans analizi yapılmıştır. Yaratıcılık puanlarının bölüm değişkenine göre ortalama ve varyans analizi sonuçları Tablo 7 ve Tablo 8'de verilmiştir. 
Tablo 7.

Yaratıılık Puanlarının Bölüm Değişkenine Göre Ortalama Değerleri.

\begin{tabular}{lccc}
\hline Bölüm & $\mathbf{N}$ & $\overline{\mathbf{X}}$ & ss \\
\hline Fen Bilgisi Öğretmenliği & 42 & 44.1667 & 14.45754 \\
Sınıf Öğretmenliği & 47 & 41.7872 & 14.55714 \\
Okul Öncesi Öğretmenliği & 47 & $\mathbf{5 1 . 4 4 6 8}$ & 17.73453 \\
Sosyal Bilgiler Öğretmenliği & 60 & 49.3667 & 16.82710 \\
Türkçe Öğretmenliği & 48 & 45.4167 & 18.33823 \\
İngilizce Öğretmenliği & 34 & 44.1176 & 15.73409 \\
\hline TOPLAM & 278 & 46.3273 & 16.63184 \\
\hline
\end{tabular}

Tablo 7 incelendiğinde, öğretmen adaylarının yaratıcılık puanlarının en yüksek Okul Öncesi Öğretmenliği bölümündeki öğretmen adaylarına ait olduğu görülmektedir.

Tablo 8.

Yaratıcılık Puanlarının Bölüm Değişkenine Göre Tek Yönlü Varyans Analizi Sonuçları.

\begin{tabular}{lrrrrrr}
\hline Bölüm & $\begin{array}{r}\text { Kareler } \\
\text { Toplamı }\end{array}$ & Sd & $\begin{array}{r}\text { Kareler } \\
\text { Ortalaması }\end{array}$ & F & P & Anlamlı Fark \\
\hline Gruplararası & 3156.760 & 5 & 631.532 & 2.337 & .042 & 1,3 \\
Grupiçi & 73466.452 & 272 & 270.097 & & & $2,3-4$ \\
Toplam & 76623.212 & 277 & & & & $3,1-2-6$ \\
& & & & & 4,2 \\
& & & & & 6,3 \\
\hline
\end{tabular}

1: Fen Bilgisi Öğretmenliği, 2: Sınıf Öğretmenliği, 3: Okul Öncesi Öğretmenliği, 4: Sosyal Bilgiler Öğretmenliği, 5: Türkçe Öğretmenliği, 6: İngilizce Öğretmenliği

Tablo 8 incelendiğinde, bölüm değişkenine göre öğretmen adaylarının yaratıcılık puanlarının anlamlı bir farklılık gösterdiği görülmektedir ( $F=2.337, p<.05)$. Başka bir deyişle, öğretmen adaylarının yaratıcılık düzeyleri, okudukları bölüme göre anlamlı bir şekilde değişmektedir. Bölümler arası farklılığın hangi gruplar arasında olduğunu bulmak üzere yapılan LSD testi sonuçlarına göre Fen Bilgisi Öğretmenliği ile Okul Öncesi Öğretmenliği; Sınıf Öğretmenliği ile Okul Öncesi Öğretmenliği ve Sosyal Bilgiler Öğretmenliği; Okul Öncesi Öğretmenliği ile Fen Bilgisi Öğretmenliği, Sınıf Öğretmenliği ve İngilizce Öğretmenliği; Sosyal Bilgiler Öğretmenliği ile Sınıf Öğretmenliği; İngilizce Öğretmenliği ile Okul Öncesi Öğretmenliği bölümleri arasında anlamlı fark olduğu tespit edilmiştir.

\section{Üçüncü Alt Probleme ilişkin Bulgular}

Üçüncü alt problem olan "Öğretmen adaylarının duygusal zekâ düzeyleri ile yaratıcılık düzeyleri arasında anlamlı bir ilişki var mıdır?” sorusunda ise, öğretmen adaylarının duygusal zekâ ve yaratıcılık puanları arasındaki ilişkiye Pearson Momentler İlişki Katsayısı ile bakılmıştır.

Tablo 9 incelendiğinde, öğretmen a dayla rının duygusal zekâ ve yaratıcılık puanları arasında çok düşük düzeyde, pozitif ve anlamlı bir ilişkinin olduğu söylenebilir $(r=.119, p<.05)$. 
Tablo 9.

Duygusal Zekâ ve Yaratıcılık Düzeyleri Arasındaki Korelasyon Analizi Sonuçları.

\begin{tabular}{llrr}
\hline & & Yaratıclık & Duygusal Zekâ \\
\hline Yaratıcılık & Pearson Korelasyon $(r)$ & 1 & $.119^{*}$ \\
& Anlamlılık $(\mathrm{p})$ & & .047 \\
& $\mathrm{~N}$ & 278 & 278 \\
\hline \multirow{2}{*}{ Duygusal Zekâ } & Pearson Korelasyon $(\mathrm{r})$ & $.119^{*}$ & 1 \\
& Anlamlılık (p) & .047 & 278 \\
& $\mathrm{~N}$ & 278 &
\end{tabular}

*Korelasyon 0,05 düzeyinde anlamlıdır.

\section{Dördüncü Alt Probleme iliş̧kin Bulgular}

“Öğretmen adaylarının öğretim süreci içinde duygusal zekâ ve yaratıcılık düzeylerini geliştirmeye yönelik fırsatlar bulunmasına ilişkin görüşleri nelerdir?" sorusuna cevap bulmak için öğretmen adayları ile yapılan görüşmeler sonucu el de edilen veriler incel enmiş ve öğretmenlerin sorulara verdikleri yanıtlar doğrultusunda ilgili bulgular aşağıda verilmiştir.

Tablo 10.

Öğretmen Adaylarının Birinci Soruya Verdikleri Cevaplar.

\begin{tabular}{|c|c|c|c|}
\hline Birinci & Çok fazla olmasa da bazı hocaların & Dördüncü & Eğitim hayatım boyunca duygulara ve \\
\hline $\begin{array}{l}\text { Sinıf } \\
\text { Kız }\end{array}$ & $\begin{array}{l}\text { derslerinde buna imkân } \\
\text { buluyorum. }\end{array}$ & $\begin{array}{l}\text { Sinıf } \\
\text { Kız }\end{array}$ & $\begin{array}{l}\text { duygusal zekâya önem veren hocalarla } \\
\text { karşılaşmadım. Belki başka üniversite ve } \\
\text { bölümlerde vardır. }\end{array}$ \\
\hline $\begin{array}{l}\text { Birinci } \\
\text { Sınıf } \\
\text { Kız }\end{array}$ & $\begin{array}{l}\text { Hayır. Genelde hocalar sunuş } \\
\text { yolunu seçtikleri için duygulara } \\
\text { önem vermiyorlar. }\end{array}$ & $\begin{array}{l}\text { Dördüncü } \\
\text { Sınıf } \\
\text { Kız }\end{array}$ & $\begin{array}{l}\text { Derslerde önemli olan hep bilgiler ve } \\
\text { sınavlar oldu. Ne hissettiğimizin bir } \\
\text { önemi olduğunu sanmıyorum. }\end{array}$ \\
\hline $\begin{array}{l}\text { Birinci } \\
\text { Sinıf } \\
\text { Erkek }\end{array}$ & $\begin{array}{l}\text { Hocaların duygulara önem verip } \\
\text { vermediğini henüz çözemedim. } \\
\text { Konuşmalarından verdiklerini } \\
\text { düşündüklerini anlıyorum, fakat } \\
\text { uygulamada göremiyorum. }\end{array}$ & $\begin{array}{l}\text { Dördüncü } \\
\text { Sınıf } \\
\text { Erkek }\end{array}$ & $\begin{array}{l}\text { Sınav ağırlıklı bir ülkede yaşıyoruz. } \\
\text { Yıllarca sınavlara girdik ve mezun } \\
\text { olduğumuzda yine gireceğiz. Duygulara } \\
\text { önem verilen bir eğitim alsaydık bu } \\
\text { kadar yarışmak zorunda kalmazdık. }\end{array}$ \\
\hline $\begin{array}{l}\text { Birinci } \\
\text { Sinıf } \\
\text { Erkek }\end{array}$ & $\begin{array}{l}\text { Bence böyle bir ortam yok. Sadece } \\
\text { yetiştirilmesi gereken konular yığını } \\
\text { var. }\end{array}$ & $\begin{array}{l}\text { Dördüncü } \\
\text { Sınıf } \\
\text { Erkek }\end{array}$ & $\begin{array}{l}\text { Ne hissettiğimizin önemli olduğu dersler } \\
\text { almadık. Sadece bir derste kendimi } \\
\text { değerli hissettim. O da hocamızın her } \\
\text { öğrenciye değer veren bir kişi } \\
\text { olmasından kaynaklanıyor. }\end{array}$ \\
\hline
\end{tabular}

Öğretmen adaylarının bu soruya verdikleri cevaplar incelendiğinde, birinci sınıf ve dördüncü sınıf düzeyindeki öğretmen adaylarının bu soruya benzer cevaplar verdikleri ve eğitim ortamlarında duygusal zekâlarını kullanacakları ortamlar bulamadıkla rını ifade ettikleri görülmektedir. Öğretmen adaylarının verdikleri cevaplar doğrultusunda öğretmen adaylarının üniversitede aldıkları derslerin bilişsel alana yönelik işlendiği buna karşın duyuşsal alana yönelik bir öğrenme-öğretme sürecine ilişkin sınıf ortamlarının düzenlenemediği ve öğretim stratejilerinin bu alanda yeterli olarak kullanılmadığı söylenebilir. 
Tablo 11.

Öğretmen Adaylarının Ikinci Soruya Verdikleri Cevaplar.

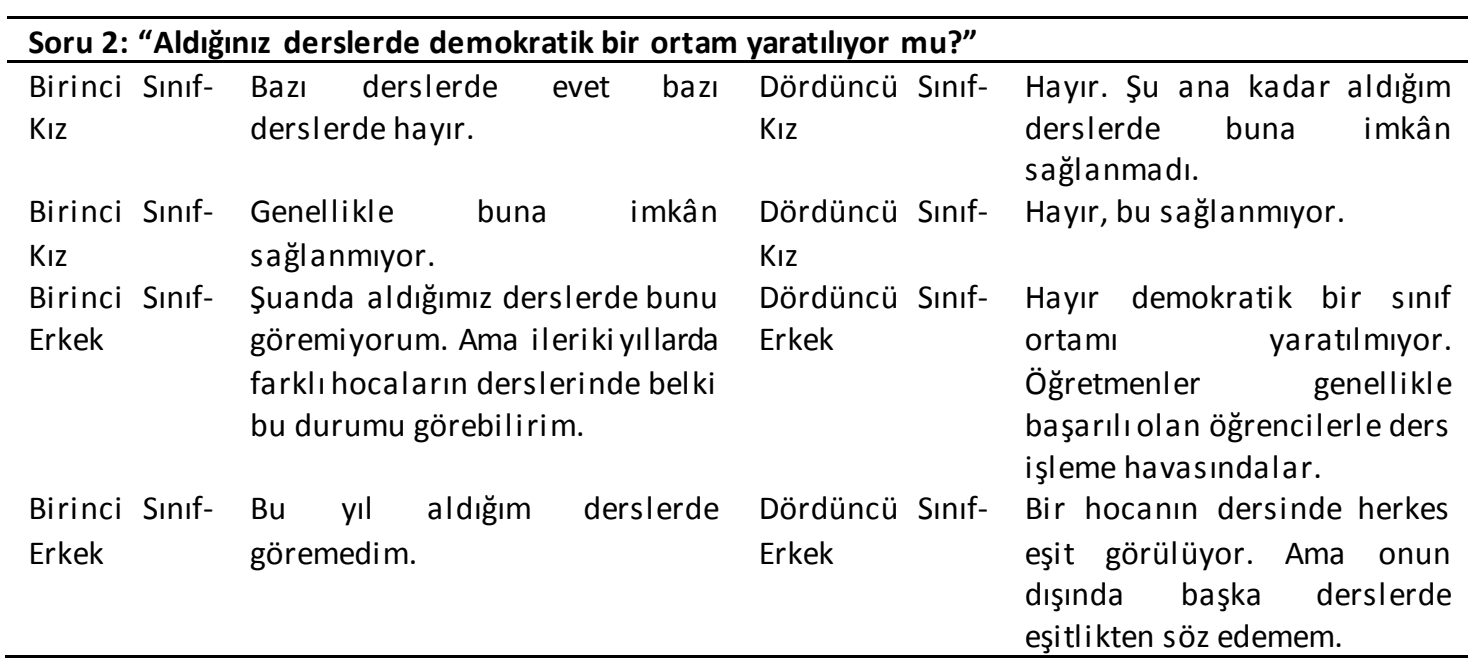

Öğretmen adaylarının bu soruya verdikleri cevaplar incelendiğinde, birinci sınıf düzeyindeki öğretmen adayları, derslerde demokratik ortamların henüz oluşamadığını ancak bu yönde bir beklenti ve umutlarının olduğuna dair görüşlerini ifade etmişlerdir. Buna karşın dördüncü sınıf düzeyindeki öğretmen adayları ise derslerde demokratik ortamların sağlanamadığını söylemişlerdir. Bu veriler incelediğinde, derslerde istenilen demokratik bir ortamın yaratılması ve öğrencilerin düşüncelerini ve duygularını özgürce söylenebilmesine ilişkin eğitim ve öğretime dair genel ve özel hedeflerin programlarda belirtilen düzeylerde ve öğrencilerin kazanımlarında tam olarak gerçekleştirilemediği söylenebilir.

Tablo 12.

Öğretmen Adaylarının Üçüncü Soruya Verdikleri Cevaplar.

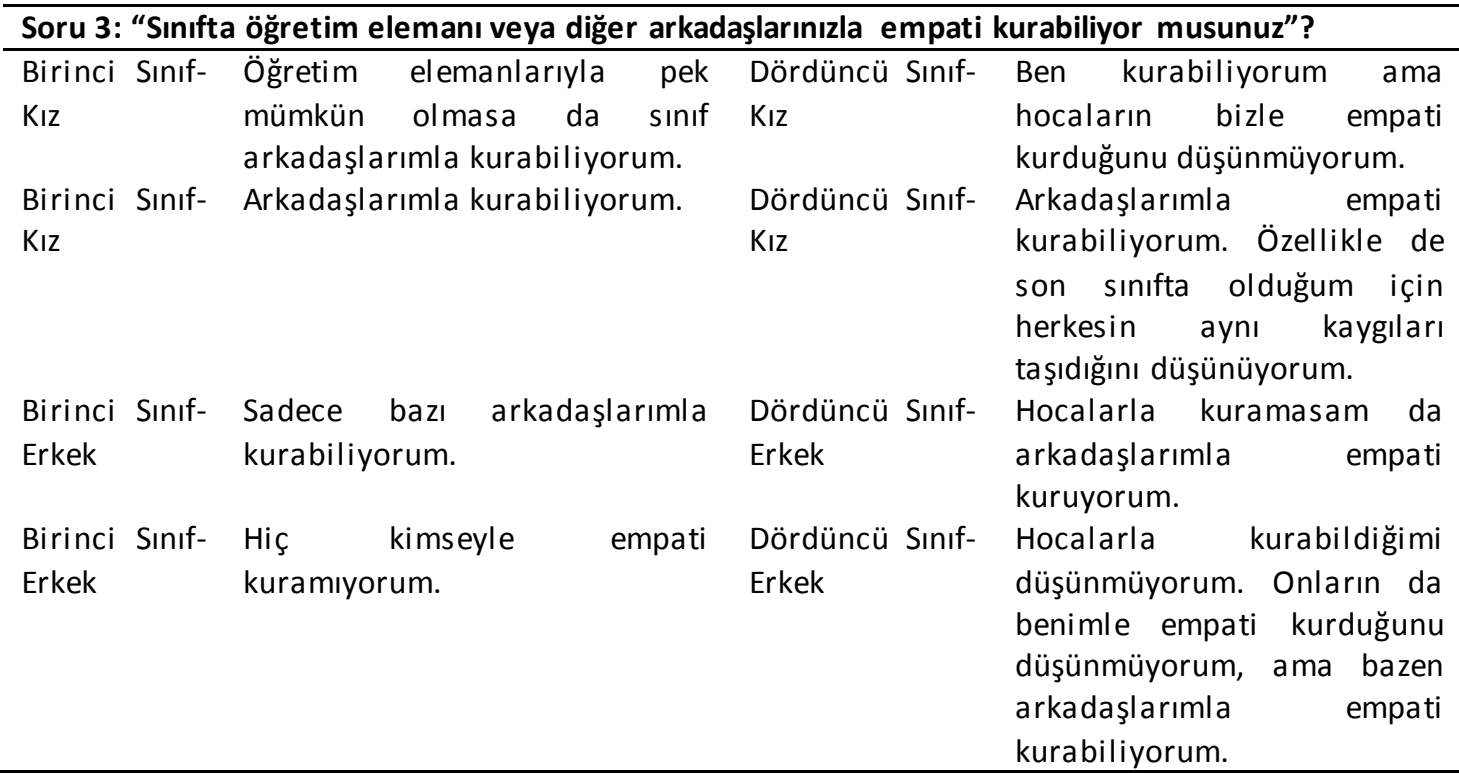

Öğretmen adaylarının bu soruya verdikleri cevaplar incelendiğinde, birinci sınıf düzeyindeki öğretmen adaylarının çoğunluğu öğretim elamanlarıyla empati kuramadıklarını, bazıları sadece 
arkadaşlarıyla kurabildiklerini, bazıları ise hiç kimseyle empati kuramadıklarını söylemişlerdir. Buna karşılık dördüncü sınıf düzeyindeki öğretmen adaylarının hem kendi içlerinde hem de birinci sınıf düzeyindeki öğretmen adaylarıyla empati konusunda farklı görüşlere sahip oldukları görülmektedir. Dördüncü sınıf düzeyindeki öğretmen adaylarının arkadaşlarıyla ve öğretim elemanlarıyla kolayca empati kurabildikleri, hatta bazılarının öğretim elemanlarının kendileri ile niçin empati kurmadıklarını da sorgulayarak empati konusunu daha fazla irdeledikleri söylenebilir. Bu cevaplar doğrultusunda, öğretmen adaylarının, duygusal zekânın bir alt boyutu olan, empati kurma becerisi, birinci sınıf düzeyinden başlayarak dördüncü sınıf düzeyine kadar farklı derslerde farklı etkinliklerle geliştirilebilir. Bu becerilerinin geliştirilmesi öncelikle öğretim elemanlarının öğrencilerle daha iyi iletişim ve etkileşim kurabilmelerine bağlıdır. Öğretim elemanları, öncelikle "pedagojik-empati stratejilerini" gözden geçirmeli, sınıftaki öğrenme süreç ve ortamlarını öğrencilerin duygusal durumlarına göre tasarlamalıdırlar.

Tablo 13.

Öğretmen Adaylarının Dördüncü Soruya Verdikleri Cevaplar.

\begin{tabular}{|c|c|c|c|c|}
\hline \multicolumn{5}{|c|}{$\begin{array}{l}\text { Soru 4: "Derslerde } \\
\text { musunuz?" }\end{array}$} \\
\hline $\begin{array}{l}\text { Birinci } \\
\mathrm{K} \mathrm{IZ}\end{array}$ & Sinıf- & $\begin{array}{l}\text { Şuan için böyle bir dersle } \\
\text { karşılaşmadım. Ama mezun } \\
\text { olana kadar yaratıcı düşünme } \\
\text { becerimi geliştirecek dersler } \\
\text { olacağına inanıyorum. }\end{array}$ & $\begin{array}{l}\text { Dördüncü Sınıf- } \\
\text { Kız }\end{array}$ & $\begin{array}{l}\text { Hayır. } 4 \text { yıllık üniversite } \\
\text { hayatım boyunca bulamadım. }\end{array}$ \\
\hline $\begin{array}{l}\text { Birinci } \\
\mathrm{K} \mathrm{IZ}\end{array}$ & Sinıf- & $\begin{array}{l}\mathrm{Bu} \text { sene aldığım derslerde } \\
\text { bulamadım. }\end{array}$ & $\begin{array}{l}\text { Dördüncü Sınıf- } \\
\text { KıZ }\end{array}$ & $\begin{array}{l}\text { Bulamıyorum. Her ders } \\
\text { birbirinin aynısı. Sunumlarla } \\
\text { dolu dersler yaratıcı } \\
\text { düşünmeye fırsat vermiyor. }\end{array}$ \\
\hline $\begin{array}{l}\text { Birinci } \\
\text { Erkek }\end{array}$ & Sinıf- & $\begin{array}{l}\text { Şuan için yaratıcı düşünmeyi } \\
\text { geliştirecek dersler almıyoruz. } \\
\text { Belki daha sonraki dönemlerde } \\
\text { alabiliriz. }\end{array}$ & $\begin{array}{l}\text { Dördüncü Sınıf- } \\
\text { Erkek }\end{array}$ & $\begin{array}{l}\text { Hayır. Çünkü } \\
\text { düşünmekten çok bilmek } \\
\text { önemli. }\end{array}$ \\
\hline $\begin{array}{l}\text { Birinci } \\
\text { Erkek }\end{array}$ & Sinıf- & Henüz böyle bir ortam oluşmadı. & $\begin{array}{l}\text { Dördüncü Sınıf- } \\
\text { Erkek }\end{array}$ & $\begin{array}{l}\text { Yaratıcı düşünmeye yönelik } \\
\text { dersler işlemiyoruz. }\end{array}$ \\
\hline
\end{tabular}

Öğretmen adaylarının verdiği cevaplar incelendiğinde, birinci sınıf düzeyindeki öğretmen adaylarının bazıları beklenti içerisinde oldukla rını, ancak yaratıcı becerilerinin gelişti rilmesine yönelik bir çabanın da olmadığına ilişkin görüş belirtmi şlerdir. Dördüncü sınıf düzeyindeki öğretmen adayları ise aldıkları eğitim süresince yaratıcı düşünme becerilerini geliştirecek orta mlar bulamadıklarını belirtmişlerdir. Bu cevaplar doğrultusunda birinci sınıf düzeyindeki öğretmen adayla rının görüşleri incelendiğinde, henüz üniversite yaşamlarının ilk dönemleri olması dolayısıyla yaratıcı düşünme becerilerinin geliştirilmesi konusunda beklenti içerisinde olduklarını, ancak şuana kadar geçen sürede yaratıcı düşünme becerilerini geliştirecek bir gelişmenin yaşanmadığı söylenebilir. Bu bulguya dayalı olarak öğretmen adaylarının aldıkları üniversite eğitiminin, bu konuda onların ihtiyaç ve beklentilerini karşılayacak düzeyde yeterli olmadığı yorumu yapılabilir.

Öğretmen adaylarının verdiği cevaplar incelendiğinde, birinci sınıf ve dördüncü sınıf düzeyindeki öğretmen adaylarının görüşlerinin farklı olduğu görülmektedir. Birinci sınıf düzeyindeki öğretmen a dayları eğitim hayatları boyunca görecekleri derslerde yaratıcı etkinlikler konusunda mesleki yeterliliğe ulaşacakları inancına sahipken, dördüncü sınıf düzeyindeki öğretmen adayları aldıkları eğitim süresince yaratıcı etkinlikler konusunda mesleki yeterliliğe ulaşamadıklarını ifade etmişlerdir. Bu cevaplar doğrultusunda öğretmen adaylarının meslek hayatlarına başlamadan önce, yaratıcı düşünme becerisini kullanabilecek yeterliliğe ulaşama dıkları, bu konuda dört yıllık öğretim süreci içerisinde aldıkları eğitimin bu anlamda bir katkı sağlamadığı düşünülebilir. 
Tablo 14.

Öğretmen Adaylarının Beşinci Soruya Verdikleri Cevaplar.

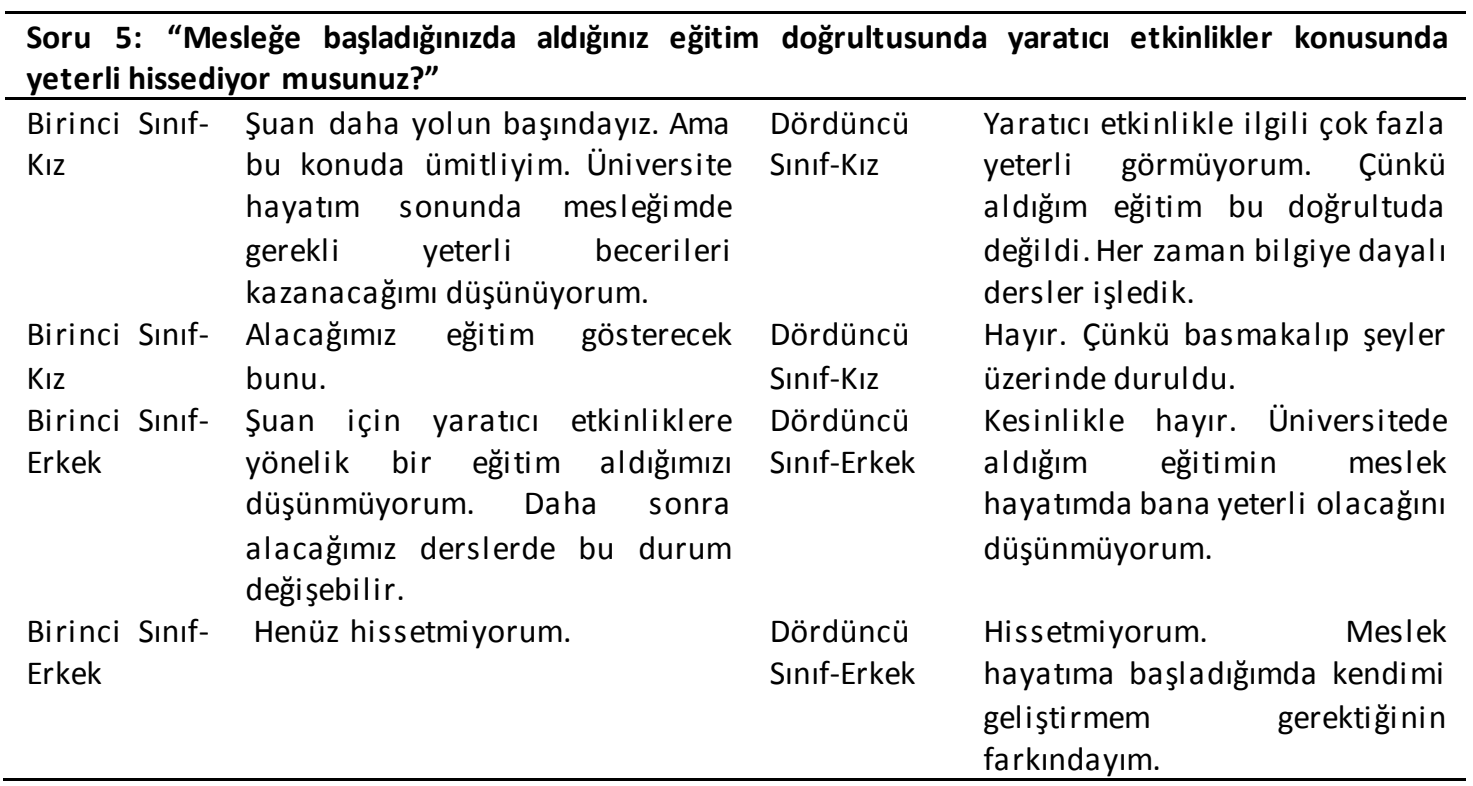

\section{Sonuç, Tartışma ve Öneriler}

Öğrenme-öğretme süreç ve ortamlarında, öğretmen adayla rının duygusal zekâ ve yaratıcılık düzeyleri arasındaki ilişkinin incelendiği bu çalışmada, öncelikle öğretmen adaylarının duygusal zekâ ve yaratıcılık puanları cinsiyet, sınıf seviyesi ve bölüm değişkenlerine göre incelenmiştir.

Elde edilen bulgulara göre, öğretmen adaylarının duygusal zekâ düzeyleri, cinsiyet değişkenine göre anlamlı bir fark göstermiştir ve bu fark kadın öğretmen adayları lehinedir. Başka bir deyişle kadın öğretmen adaylarının duygusal zekâ düzeyleri, erkek öğretmen adaylarının duygusal zekâ düzeylerinden daha yüksektir. Bircan (2004), Erdoğdu (2008) ve Göcet (2006)'in yaptıkları çalışmalarda da, duygusal zekâ ile cinsiyet arasında kadınlar lehine anlamlı farklılıklar bulunmuştur. Bu çalışmaların sonuçları, çalışmamızda elde edilen bu bulgu ile paralellik göstermektedir. Duygusal zekânın küçük yaşlardan itibaren yetiştirilme durumuna göre şekillendiği ve Türk toplumunda kadının sosyal konumu dikkate alındığında bu sonucun şaşırtıcı olmadığı söylenebilir. Çünkü toplumumuzda kadına yüklenen roller, onların daha fazla sosyal sorumluluk taşımalarını gerektirmektedir. Bu anlamda kadınların erkeklere oranla duygularının daha çok farkında olmaları, daha çok empati göstermeleri, daha çok sosyal sorumluluğa sahip olmaları gibi etmenlerin, onların duygusal zekâ düzeylerinin erkeklerin duygusal zekâ düzeylerinden daha yüksek olmasını sağladığı düşünülebilir.

Yapılan analizler sonucunda öğretmen adaylarının duygusal zekâ düzeylerinin sınıf seviyesi değişkenine göre anlamlı bir şekilde farklılaşmadığı görülmüştür. Tekin Bender (2006)'in yaptığı çalışmada, öğrencilerin duygusal zekâ düzeylerinin öğrenim görülen sınıf düzeyine bağlı olarak hiçbir duygusal zekâ boyutunda anlamlı bir şekilde değişme olmadığı sonucu, çalışmamızın bu bulgusu ile benzerlik göstermektedir. Birinci sınıf ve dördüncü sınıf öğretmen a daylarının duygusal zekâ düzeylerinin anlamlı bir farklılık göstermemesi, onlara sağlanan eğitimin duygusal zekâlarını geliştirecek yönde olmadığı düşüncesini akla getirmektedir. Öğretmen adaylarıyla yapılan görüşmelerden elde edilen bulgular da öğretmen adaylarının duygusal zekâ yetkinliklerini kazanacakları ve bu yetkinlikleri geliştirecekleri bir eğitim-öğretim ortamına sahip olmadıkları görüşünü desteklemektedir.

Öğretmen adaylarının duygusal zekâ düzeylerinin okudukları bölümlere göre değişim gösterip göstermediğini incelemek üzere yapılan analizlerden elde edilen bulgular, öğretmen adaylarının duygusal zekâ düzeylerinde okudukları bölüme göre bir farklılık olmadığını göstermektedir. Benzer bir 
çalışmada Önen (2008), bölümlere göre öğretmen adaylarının duygusal zekâ düzeyleri arasında ciddi farklılıklar olmadığını, fen bilgisi bölümünde öğrenim gören öğretmen adaylarının daha yüks ek duygusal zekâ ortalamaları sergilemelerine rağmen bu farkın anlamlı olmadığını belirtmiştir.

Öğretmen adaylarının yaratıcılık düzeylerinin cinsiyet değişkenine göre analizi sonucunda, cinsiyetin, öğretmen adaylarının yaratıcılık düzeyini etkilemediği görülmüştür. Bu sonuçlara benzer olarak Yenilmez ve Yolcu (2007), yaptıkları araştırmada kadın ve erkek ilköğretim öğretmenlerinin yaratıcılıklarında cinsiyetin anlamlı bir farklılık oluşturmadığını tespit etmişlerdir.

Elde edilen analiz sonuçlarına göre öğretmen adaylarının yaratıcılık düzeyleri sınıf seviyesine göre değişmemiş, birinci ve dördüncü sınıf öğretmen adaylarının yaratıcılık puanları arasında anlamlı bir farklılık ol uşma mıştır. Yıldız, Zırhlıoğlu, Yal çınkaya ve Güven (2011), çalışmalarında yaratıcılık pua nlarının sınıf düzeyine göre anlamlı bir farklılık göstermediğini belirtmişlerdir. Bu çalışmanın sonucu, elde edilen bu bulguyu destekleyecek yöndedir. Öğretmen adaylarının yaratıcılık düzeylerinin sınıf seviyesine göre değişiklik göstermemesi, onların yetiştirildiği eğitim programlarının yaratıcılık becerisini geliştirecek yönde ol madığını ya da uygulanamadığını düşündürmektedir. Nitel verilerden elde edilen bulgulara göre, birinci sınıfta öğrenim gören öğretmen adayları alacakları eğitimle ya ratıcılık becerilerinin gelişeceği yönünde bir beklenti içinde öğrenime başlarken, dördüncü sınıfta öğrenim gören öğretmen adayları yaratıcılık becerilerinin gelişmediği fikri ile mezun olup mesleğe bu şekilde başlamaya hazırlanmaktadırlar. Bu durum bize öğretmen adaylarının üniversite öğrenim hayatlarında yaratıcılık becerilerini geliştirme üzerine beklentilerini karşılayacak eğitim-öğretim ortamını bulamadıklarını göstermektedir.

Öğretmen adaylarının yaratıcılık düzeylerinin okudukları bölümlere göre inc el endiği analizlerden elde edilen sonuçlara göre, öğretmen a daylarının yaratıcılık düzeylerinin okudukları bölümlere göre değiştiği, Fen Bilgisi Öğretmenliği ile Okul Öncesi Öğretmenliği; Sınıf Öğretmenliği ile Okul Öncesi Öğretmenliği ve Sosyal Bilgiler Öğretmenliği; Okul Öncesi Öğretmenliği ile Fen Bilgisi Öğretmenliği, Sınıf Öğretmenliği ve İngilizce Öğretmenliği; Sosyal Bilgiler Öğretmenliği ile Sınıf Öğretmenliği; İngilizce Öğretmenliği ile Okul Öncesi Öğretmenliği bölümleri arasında anlamlı fark olduğu tespit edilmiştir. Temizkalp (2010), bu bulguyu destekleyen çalışmasında, öğretmen adaylarının yaratıcılık düzeylerinin okudukları bölümlere göre farklılık gösterdiğini belirtmiştir.

Öğretmen adaylarının duygusal zekâ ve yaratıcılık düzeyleri arasındaki ilişkiye dair elde edilen bulgulara göre, öğretmen adaylarının duygusal zekâ ve yaratıcılık düzeyleri arasında pozitif yönde anlamlı bir ilişki bulunduğu görülmektedir. Cengiz, Acuner ve Baki (2006), yaptıkları çalışmada yaratıcılığın bir süreç olduğunu ve her süreçte de duygusal zekânın yaratıcılığın gelişmesine katkıda bulunup, süreci kolaylaştırdığını ifade etmişlerdir. Benzer bir çalışmada Dadvar, Mohamadrezaii ve Fathabadi (2012), duygusal zekâ ile yaratıcılık arasında pozitif yönde ve anlamlı bir ilişki bulunduğunu, duygusal zekânın öğrencinin yaratıcılığını etkilediğini ve duygusal zekânın bileşenlerinin öğrencideki yaratıcılık düzeyini tahmin etmemizi sağlayabileceğini belirtmişlerdir. Bu çalışmaların sonuçları, elde edilen bu bulgu ile paralellik göstermektedir ve duygusal zekâ ile yaratıcılık arasında bir ilişkinin olduğu öngörümüzü desteklemektedir. O hâlde bireyde yaratıcı düşünme gibi üst düzey düşünme becerilerinin geliştirilmesi hususunda, duygusal zekâ yetkinliklerinin de dikkate alınması ger ekmektedir.

Öğretmen adaylarının öğrenme-öğretme süreç ve ortamları içinde duygusal zekâ ve yaratıcılık düzeylerini geliştirmeye yönelik fırsatlar bulunmasına ilişkin birinci sınıf ve dördüncü sınıf düzeyindeki öğretmen adaylarının görüşleri incelenmiştir. Birinci sınıf düzeyindeki öğretmen adaylarının duygusal zekâ ve yaratıcı becerilerinin geliştirilmesi konusunda beklenti ve ümit içerisinde olmalarına rağmen henüz bu konularda bir çaba ve etkinliklere rastlamadıkları belirlenmiştir. Bununla paralel ola rak dördüncü sınıf düzeyindeki öğretmen adaylarının ise duygusal zekâ ve yaratıcılık becerilerinin öğrenilmesi ve öğretilmesi konusunda hayal kırıklığı yaşadıklarına ilişkin görüşlerinin ön planda olduğu saptanmıştır. Öğretmen adayları birinci sınıf düzeyinde duygusal zekâ ve yaratıcılık becerilerinin geliştirilebileceğine inanırken, dördüncü sınıf düzeyinde buna yönelik bir ortam oluşturulmadığı görüşlerini belirtmişlerdir. Öğretmen adaylarıyla nitel görüşmeler çerçevesinde elde edilen bulgulara 
dayalı olarak, öğretmen adaylarının üniversitede aldıkları derslerin bilişsel alana yönelik işlendiği buna karşın duyuşsal alana yönelik bir öğrenme-öğretme sürecine ilişkin sınıf ortamlarının düzenlenemediği; derslerde demokratik ortamlar bulamadıkları; öğretmen adaylarının empati kurma becerilerinin yeterince geliştirilemediği, buna karşılık bireysel farkındalığı olan öğrencilerin derslerde oluşturulan ortam ve süreçlerden değil de kendi yeteneklerinden dolayı empati kurabildikleri; yaratıcı becerilerinin geliştirilmesi için hem dersler bağla mında hem de dersler içerisinde ya pılan etkinlikler bağlamında yeterli düzeylerde çabanın olmadığı; öğretmen adaylarının meslek hayatlarına başlamadan önce üst düzey düşünme becerilerinden yaratıcı düşünme becerisini kullanabilecek yeterliliğe ulaşamadıkları, sonuçlarına vurgu yapılabilir.

Araştırmadan elde edilen bulgular ışığında öğretmen adaylarının duygusal zekâ ve yaratıcılık düzeylerinin geliştirilmesi adına şu önerilerde bulunulabilir:

1.Bu araştırmanın sonuçları, bulguların elde edildiği örneklem ile sınırlıdır. Bu nedenle çalışmanın sonuçlarının tüm öğretmen adaylarına genellenmesi beklenemez. Araştırma sonuçlarının genellenebilirliğinin artırılması için farklı üniversiteden öğretmen adaylarını da içeren daha kapsamlı bir örneklem ile benzer çalışmalar yapılabilir.

2.Öğretmen ve öğretmen adaylarının duygusal zekâ ve yaratıcılık düzeyleri arasındaki ilişkinin incelendiği çalışmaların sayısı artırılarak ilgili alandaki boşluk doldurul abilir. Duygu düşünceyi, düşünce duyguyu besler ilkesi gereği derslerdeki etkinliklerde duygu-düşünce matrikslerine dayalı etkinliklere yer verilmelidir.

3.Araştırmamız neticesinde öğretmen adaylarının aldıkları eğitimle duygusal zekâ ve yaratıcılık düzeylerinin anlamlı bir değişim göstermediği görülmektedir. Bu hususta öğretmen yetiştiren kurumlardaki eğitim programlarının kazanım, içerik, öğrenme-öğretme süreci ve ölçmedeğerlendirme boyutlarının duygusal zekâ ve yaratıcılık ile ilgili ola rak yapılandırılması, programın uygulayıcıları olan öğretim elemanlarının bu becerilerin geliştirilmesi konusunda daha titiz davranmaları ile öğretmen adaylarının üniversite eğitimleri sonucunda duygusal zekâ ve yaratıcılık düzeylerinin yüksel tilmesi sağlanabilir.

4.Öğretmen adaylarının duygusal zekâ ve ya ratıcılık düzeylerini geliştirebilecekleri okul ortamla rının fiziki şartları ve bu şartların iyileştirilmesi konusunda çalışmalara ağılık verilmelidir.

\section{Kaynakça}

Akkan, E. (2010). Orta öğretimdeki üstün yetenekli öğrencilerin duygusal zekâ ve yaratıclık düzeylerinin yaşam doyumlarını yordama gücü. Unpublished master thesis. Gaziosmanpaşa Üniversitesi, Sosyal Bilimler Enstitüsü, Tokat.

Aksoy, B. (2004). Coğrafya öğretiminde probleme dayalı öğrenme yaklaşımı. Unpublished master thesis. Gazi Üniversitesi, Eğitim Bilimleri Enstitüsü, Ankara.

Arık, A. İ. (1987). Yaratıılık (Üç derleme). Ankara: Kültür ve Turizm Bakanlığı Yayınları.

Bircan, S. (2004). Ergenlerin duygusal zekâlarının çatışma eğilimlerine ve suç davranışlarına etkisi. Unpublished master thesis. Gazi Üniversitesi, Eğitim Bilimleri Enstitüsü, Ankara.

Cengiz, E., Acuner, T., \& Baki, B. (2006). Liderlerin sahip oldukları duygusal zekânın örgütsel yaratıcılık üzerine etkileri: Bir model önerisi. Sosyal Bilimler Enstitüsü Dergisi, 7(1), 421-434.

Coetzee, M. \& Jansen, C. (2007). Emotional intelligence in the classroom. Cape Town: Juta.

Cooper K.R. \& Sawaf A. (2000). Liderlikte duygusal zekâ. İstanbul: Sistem Yayıncılık.

Creswell, J. W. (1998). Qualitative inquiry and research design: Choosing among five traditions. London: Sage Publications. 
Bilal DUMAN, Güler GÖÇEN ve Ali YAKAR - Pegem Eğitim ve Öğretim Dergisi, 4(2) 2014, 45-74

Çellek, T. (2005, 6 Aralık). Geleceğin şekillenmesi için eğitimde yaratıılık. Retrieved Agust 22, 2012, from http://www.netyorum.com/sayi/165/20051206-14.htm.

Çetingöz, D. (2002). Okul öncesi eğitimi öğretmenliği öğrencilerinin yaratıcı düşünme becerilerinin gelişiminin incelenmesi. Unpublished master thesis. Dokuz Eylül Üniversitesi, Eğitim Bilimleri Enstitüsü, İzmir.

Dadvar, R., Mohamadrezaii, M. \& Fathabadi, M. H. (2012). The relationship between emotional intelligence and creativity of female high school students in Baft city. Journal of Basic and Applied Scientific Research, 2(4), 4174-4183.

Duman, B. (2007). Neden beyin temelli öğrenme?. Ankara: Pegem Akademi Yayınları.

Dutoğlu, G. \& Tuncel, M. (2008). Aday öğretmenlerin eleştirel düşünme eğilimleri ile duygusal zekâ düzeyleri arasındaki ilişki. Abant İzzet Baysal Üniversitesi Eğitim Fakültesi Dergisi, 8(1), 11-32.

Erdoğdu, M.Y. (2008). Duygusal Zekâ'nın Bazı Değişkenler Açısından Incelenmesi. Elektronik Sosyal Bilimler Dergisi, 7(23), 62-76.

Goleman, D. (2000). İşbaşında duygusal zekâ (H. Balkara, Trans.). İstanbul: Varlık Yayınları.

Goleman, D. (2005). Duygusal zekâ neden IQ'dan daha önemlidir? (B. Seçkin, Trans.). İstanbul: Varlık Yayınları.

Göcet, E. (2006). Üniversite öğrencilerinin duygusal zekâ düzeyleri ile stresle başa çıkma tutumları arasındaki ilişki. Unpublished master thesis. Sakarya Üniversitesi, Sosyal Bilimler Enstitüsü. Sakarya.

Yıldız, L., Zırhlıoğlu, G., Yalçınkaya, M., \& Güven, Ş. (2011). Beden eğitimi öğretmen adaylarının yaratıcılık ve problem çözme becerileri. Yüzüncü Eğitim Fakültesi Dergisi, Özel Sayı, 18-36.

Hatch, J. A. (2002). Doing qualitative research in education settings. New York: State University of New York Press.

Karasar, N. (2005). Bilimsel araştırma yöntemi. Ankara: Nobel Yayın Dağıtım.

Kocayörük, A. (2004). Duygusal zekâ eğitiminde drama etkinlikleri. Ankara: Nobel Yayın Dağıtım.

Mayer, J. D. \& Salovey, P. (1993). The intelligence of emotional intelligence. Intelligence, 17(4), 433-442.

Merriam, S. B. (1998). Qualitative research and case study applications in education. San Francisco: Jossey-Bass Publishers.

Orhon, G. (2011). Yaratıclık; nörofizyolojik, felsefi ve eğitsel temeller. Ankara: Pegem Akademi.

Önen, Ö. (2008). Öğretmen adaylarının duygusal zekâ düzeyleri ve etik muhakeme yetenekleri. Unpublished master thesis. Süleyman Demirel Üniversitesi, Sosyal Bilimler Enstitüsü, Isparta.

Özcan, A. O. (2000). Algıdan yoruma yaratıcı düşünce. İstanbul: Avcıol Basım Yayın.

Özözer, Y. (2008). Ne parlak fikir. İstanbul: Sistem Yayıncılık.

Öztürk Ş. A. \& Darıca N. (2003). Çocuk gelişimi ve okul öncesi eğitimi öğretmenliği, anaokulu öğretmenliği ve okul öncesi öğretmenliği lisans programlarında yer alan yaratıcılık ile ilgili der slere ilişkin görüşler. Eğitim Araştırmaları, 4(13), 10-21.

Rawlinson, J. G. (1995). Yaratıcı düşünme ve beyin fırtınası (O. Değirmen, Trans.). İstanbul: Rota Yayın.

Saaty, T. L. (2006). Creative thinking, problem solving and decision making. Pittsburgh: RWS Publication.

Salovey, P. \& Mayer, J. D. (1990). Emotional intelligence. Imagination, cognition and personality, 9, 185211.

San, İ. (2002). Yaratıcı drama 1985-1995 yazıları. Ankara: Natürel Yayınları.

Schutte, N.S., Malouff, J.M., Hall, L.E., Haggerty, D.J., Cooper, J.T., Golden, C.J. \& Dornheim, L. (1998). Development and validation of a measure of emotional intelligence. Personality and individual differences, 25, 167-177. 
Bilal DUMAN, Güler GÖÇEN ve Ali YAKAR - Pegem Eğitim ve Öğretim Dergisi, 4(2) 2014, 45-74

Senemoğlu, N. (2005). Gelişim, öğrenme ve öğretim; kuramdan uygulamaya. Ankara: Spot Matbaacılık.

Tatar, A., Tok, S. \& Saltukoğlu, G. (2011). Gözden geçirilmiş Schutte Duygusal Zekâ Ölçeği'nin Türkçe'ye uyarlanması ve psikometrik özelliklerinin incelenmesi. Klinik Psikofarmakoloji Bülteni, 21(4), 325338.

Tekin Bender, M. (2006). Resim-iş eğitimi öğrencilerinde duygusal zekâ ve yaratıcılık ilişkileri. Unpublished doctoral dissertation. Dokuz Eylül Üniversitesi, Eğitim Bilimleri Enstitüsü, İzmir.

Temizkalp, G. (2010). Öğretmen adaylarının yaratıcılık düzeyleri. Unpublished master thesis. Mehmet Akif Ersoy Üniversitesi, Sosyal Bilimler Enstitüsü, Burdur.

Torrance, E. P. (1995). Why to fly? A philosophy of creativity. New Jersey, Norwood: Ablex Publishing Corporation.

Whetton, D.A. \& Cameron, K.S. (2002). Developing management skills. Upper Saddle River: Prentice Hall.

Yenilmez, K. \& Yolcu, B. (2007). Öğretmen davranışlarının yaratıcı düşünme becerilerinin gelişimine katkısı. Osmangazi Üniversitesi Sosyal Bilimler Dergisi, 18, 96-105.

Yıldırım, A. \& Şimşek, H. (2005). Sosyal bilimlerde araştırma yöntemleri. Ankara: Seçkin Yayıncılık.

Zhou, J. \& George, J. M. (2003). Awakening employee creativity: The role of leader emotional intelligence. The Leadership Quarterly, 14, 545-568. 